\title{
Cognitive distinction of students with specific learning disorder versus students with learning problem: The roles of working memory, processing speed and problem solving
}

\author{
Kamal Parhoon $^{1}$, Hamid Alizadeh²" (iD), Hamid Reza Hassanabadi ${ }^{3}$, Mahdi Dastjerdi Kazemi ${ }^{4}$ \\ 1. PhD in Psychology of Exceptional Children, Allameh Tabataba'i University, Tehran, Iran \\ 2. Professor, Department of Psychology \& Education of Exceptional Children, Allameh Tabataba'i University, Tehran, Iran \\ 3. Assistant Professor, Department of Educational Psychology, Kharazmi University, Tehran, Iran \\ 4. Assistant Professor, Department of Psychology \& Education of Exceptional Children, Allameh Tabataba'i University, Tehran, Iran
}

Recieved: 23 Oct. 2018

Revised: 26 Dec. 2018

Accepted: 1 Jan. 2019

\section{Keywords}

Specific learning disorder

Learning problem

Working memory

Processing speed

Problem-solving

\section{Corresponding author}

Hamid Alizadeh, Professor, Department of Psychology \& Education of Exceptional Children, Allameh Tabataba'i University, Tehran, Iran

Email: Halizadeh@atu.ac.ir

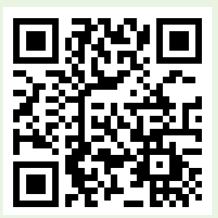

\section{Abstract}

Introduction: The purpose of this study was to investigate the role of working memory, processing speed, and problem-solving in the cognitive distinction of students with a special learning disorder and learning problem.

Methods: In this causal-comparative study, the participants constituted 100 students with specific learning disorder and 100 students with learning problems who were matched based on age, gender, grade and IQ. The major evaluation tools in this study included The Learning Disability Evaluation Scale-Renormed Second Edition (LDES-R2), Wechsler Intelligence Scale for Children-IV (WISC-IV), Behavioral Rating Scale of Executive Functions (BRIEF) and Tower of London test. The data were analyzed using the multivariate analysis of variances (MANOVA).

Results: Specific learning disorder in working memory, processing speed and problem-solving were significantly weaker than students with learning difficulties $(\mathrm{P}<0.001)$. Thus, based on mentioned variables, it can be distinguished the group of students with specific learning disorder from the group of students with learning difficulties.

Conclusion: According to the results of this study, attention to the executive functions such as working memory, processing speed and problem solving in education as well as rehabilitation of students with a specific learning disorder and learning problem can lead to effective results.

Citation: Parhoon K, Alizadeh H, Hassanabadi HR, Dastjerdi Kazemi M. Cognitive distinction of students with specific learning disorder versus students with learning problem: The roles of working memory, processing speed and problem solving. Advances in Cognitive Sciences. 2019;21(3):18-30. 


\title{
تمايز شناختى دانش آموزان با اختلال يادكيرى ويزه و مشكل يادكيرى: نقش حافظه كارى، سرعت يردازش و حل مسأله
}

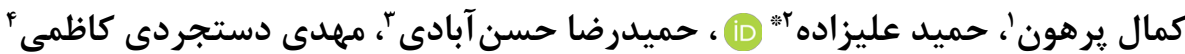

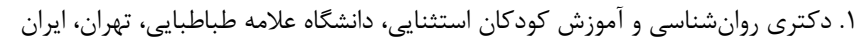

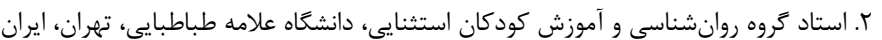

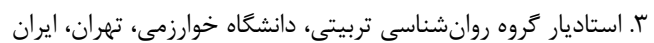

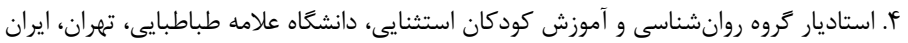

\section{(S)}

مقلهمه: يروهش حاضر با هدف بررسى نقش حافظه كارى، سرعت يردازش و حل مسأله در تمايز شناختى دانش آموزان

$$
\text { اختلال يادكيرى ويثه و مشكل يادَيرى انجام گرفت. }
$$

روش كار: در اين يزوهش على_مقايسهاى، از بين تمامى دانش آموزان ^ تا זا سال مراجعهكننده به مراكز اختلال

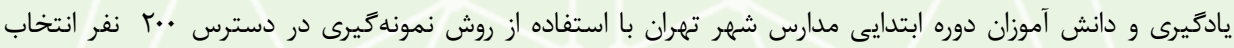

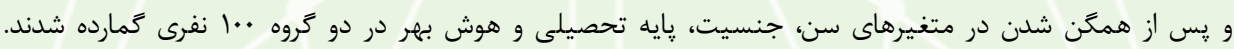
دادههاى يروهش با استفاده از ويراست دوم مقياس ارزيابى اختلال يادكيرى، ويراست جهارم هوش وكسلر كودكان، مقياس درجهبندى رفتارى كاركردهاى اجرايى و آزمون بج لندن كردآورى و از طريق روش آمارى تحليل واريانس جند متغيرى مورد تجزيه و تحليل قرار كرفت. يافته ها: نتايج تحليل واريانس حند متغيرى نشان داد كه عملكرد دانش آموزان با اختلال يادكيرى ويثه در حافظه كارى،

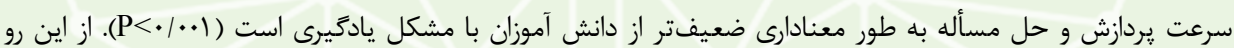
بر اساس اين سه متغير مىتوان گروه دانش آموزان با اختلال يادكيرى ويزه را از كروه دانش آموزان با مشكل يادكيرى

$$
\text { متمايز كرد. }
$$

نتيجه گَيرى: با توجه به نتايج به دست آمده از يروهش حاضر توجه به كاركردهاى اجرايى از جمله حافظه كارى، سرعت بردازش و حل مسأله مى تواند در تشخيص به هنَام، آموزش و توانبخشى دانش آموزان با اختلال يادكيرى ويرهه و مشكل

$$
\text { يادگيرى نتايج اميدبخشى در يى داشته باشد. }
$$

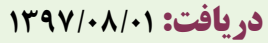

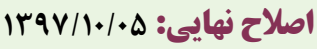

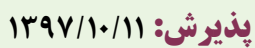

وازمهاى كليلدى

اختلال يادخيرى ويثر

مشكل يادگيرى

حافظه كارى

سرعت ڤردازش حل مسأله

نويسنده مسئول

حميد عليزاده، استاد گروه روانشناسى و آموزش كودكان استثنايى، دانشعاه علامه عليز

طباطبايى، تهران، ايران

ايميل:Halizadeh@atu.ac.ir

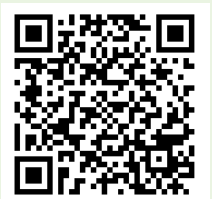

dol doi.org/10.30699/icss.21.3.18

مقدمه

خواندن، بيان نوشتارى و رياضى است كه در اوايل كودكى شروع و با توانايىهاى هوشى كلى كودى همخوانى ندارد. مشكلات تحصيلى اين كودكان شامل مشكلات يادگيرى و به كارگيرى مهارتهاى تحصيلى از جمله روخوانى دشوار، كند و نادرست كلمات، ناتوانى در درك معنى كلمات خوانده شده، مشكلات هجى كردن، اشكال در بيان
اختلال يادگيرى ويزه در كودكان يك اختلال مبتنى بر كاركردهاى عصب شناختى است كه در طى تحول بر اثر تعامل عوامل زنتيكى و محيطى به وجود مى آيد و بر توانايىهاى مغزى در ادراى يا يردازش مؤثر اطلاعات كلامى يا غير كلامى تأثير مى گذارد. مشخصه اين اختلال مشكلات يايدار در زمينه يادگيرى مهارتهاى تحصيلى مربوط به 
در ارتباط است و نقش بسيار مهم و انكار نايذيرى در يادگيرى و كسب موفقيتهاى تحصيلى ايفا مى كند. بر اساس مدل Baddeley (1- • (1)

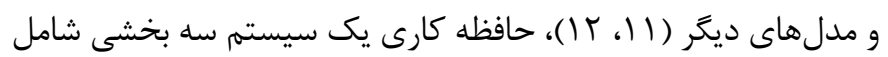

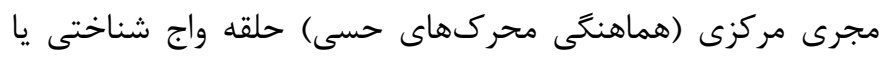

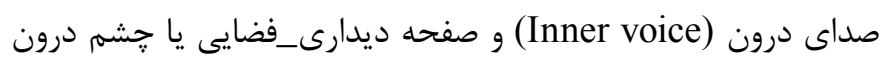
(Inner eye)

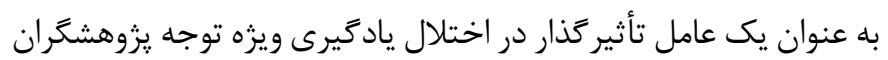

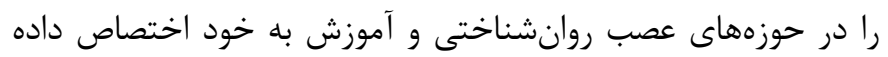

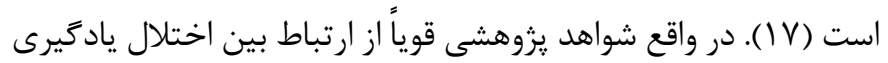
ويزهه و نقص در حافظه كارى حمايت مى كنند (1) -• (؟). در يك مطالعه

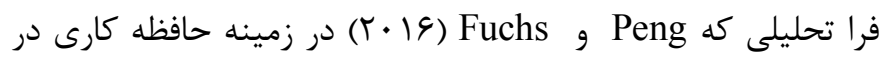

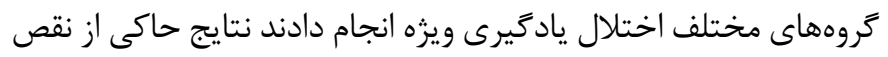

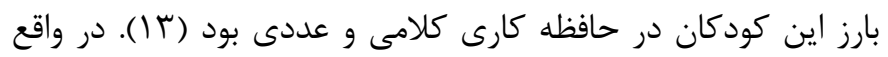
بر اساس مدل حافظه كارى Baddeley مشكل كودكان داراى اختلال

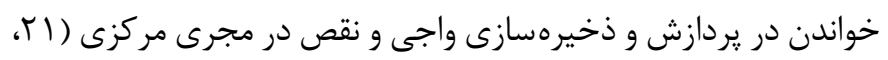

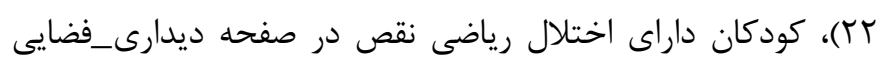

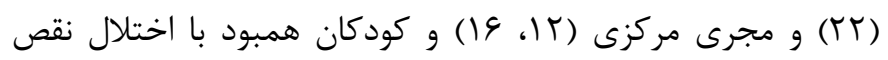

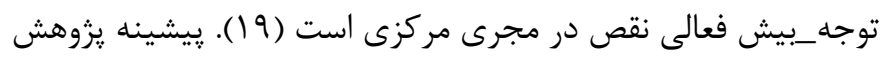

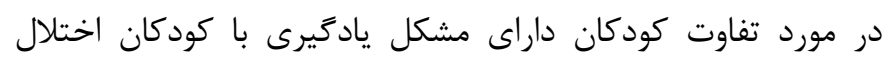

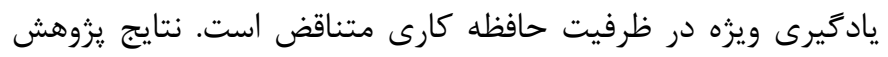

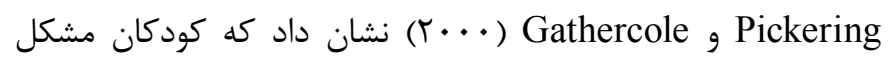
يادگيرى در مدل حافظه كارى Baddeley در مجرى مركزى و حافظه

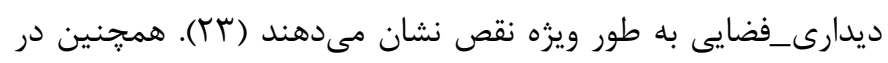

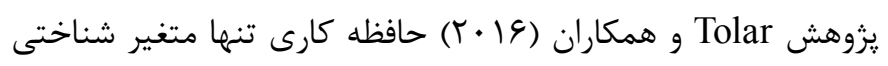
بود كه بين گروه كودكان با مشكل يادكيرى و كروه با اختلال يادكيرى

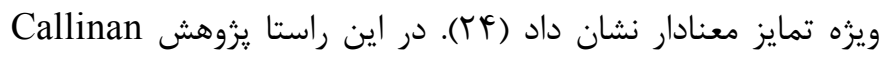

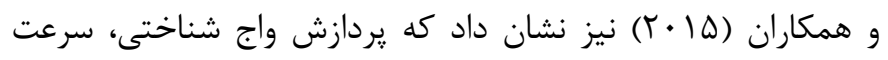

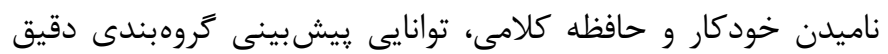

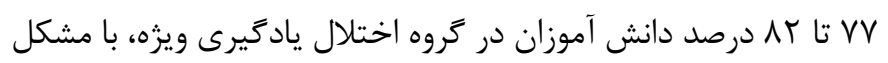

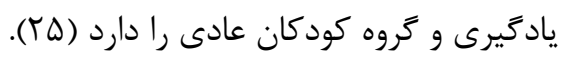

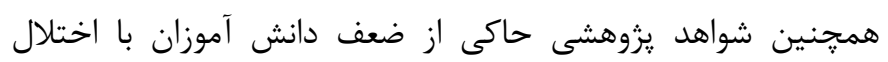

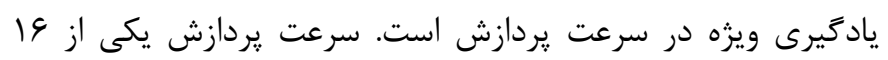

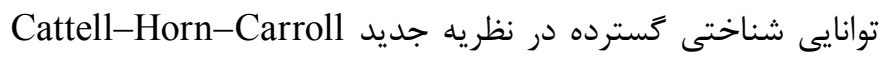
است كه شامل ينج توانايى خرد شناختى (سرعت ادراى،

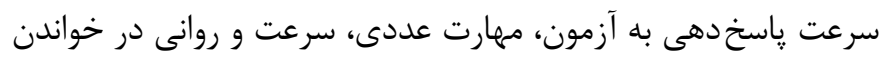

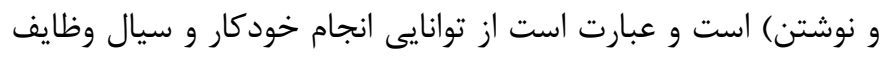

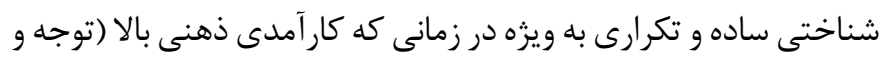

نوشتارى، يادگيرى مفاهيم و معانى اعداد و يا محاسبات و استدلال

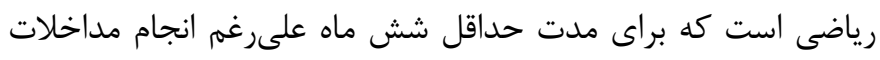
درمانى براى رفع مشكلات فوق وجود داشته باشد. شيوع اين اختلال

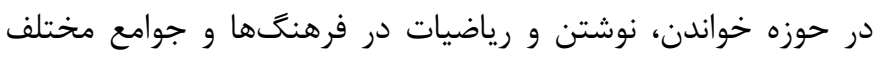

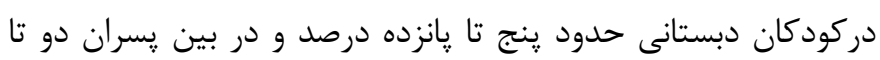

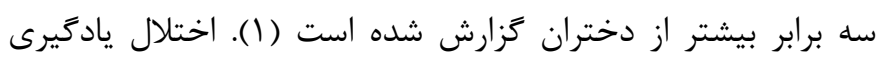

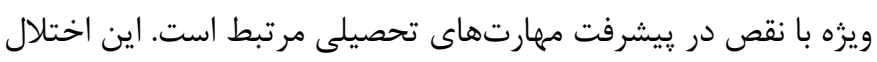

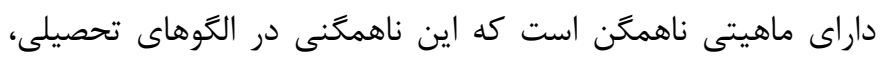

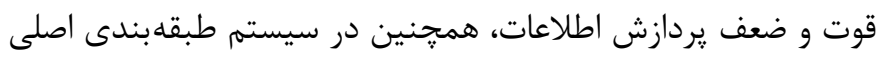

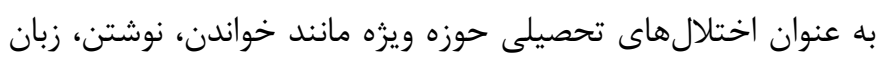

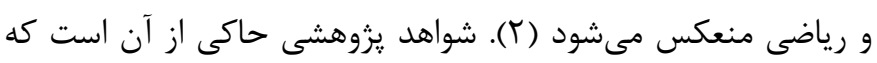

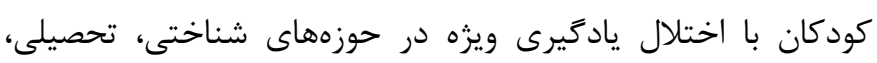

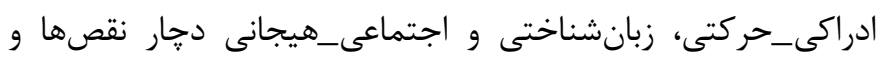

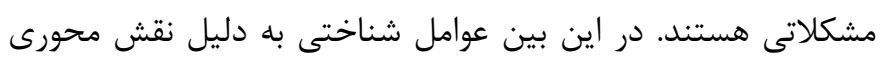

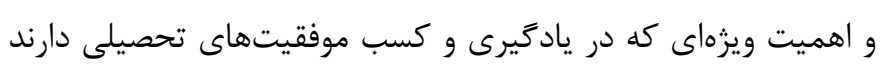

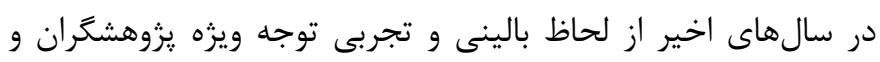

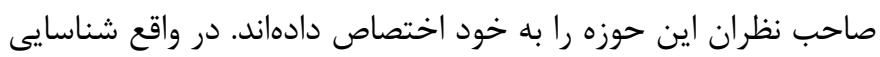

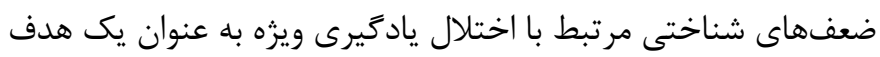

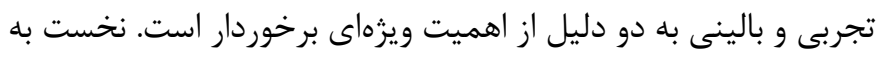

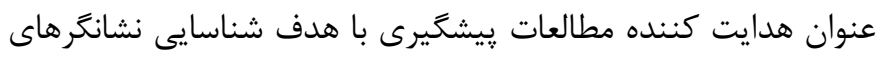

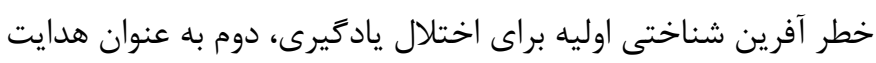

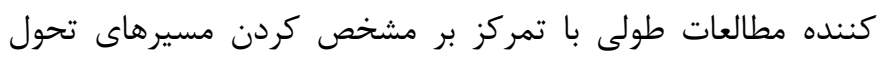

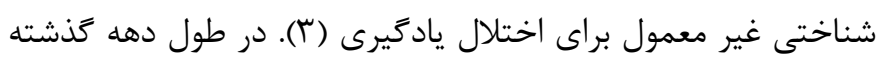

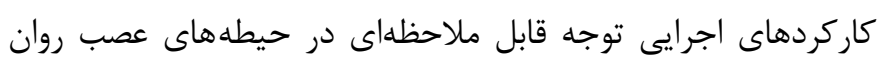

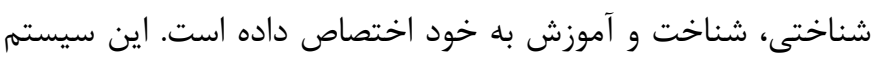

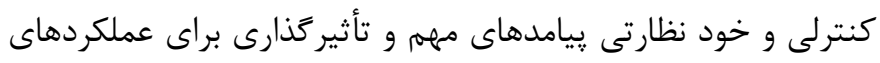

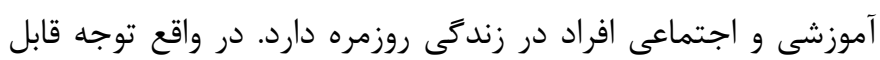

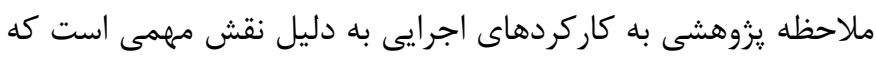

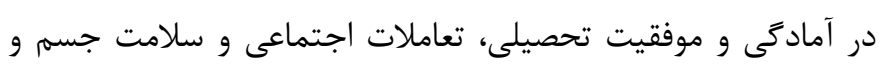

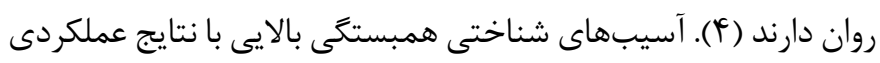

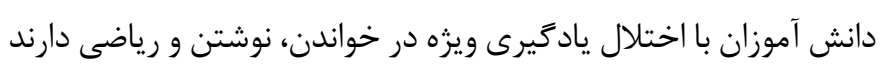

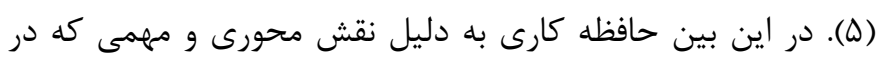

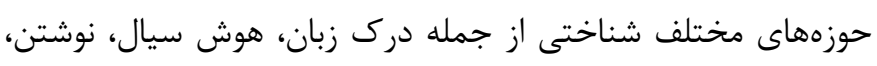

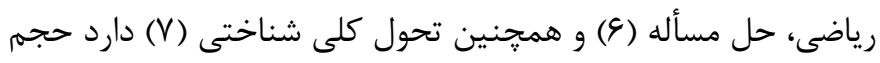

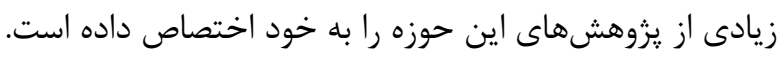

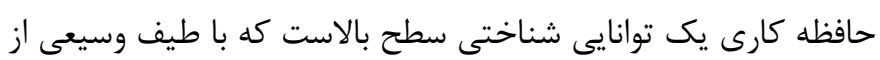

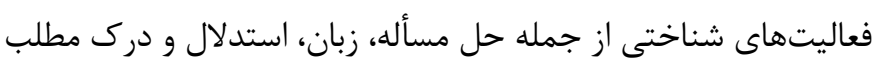


اختلال از مشكل يادكيرى بايد تمايز قائل باشيه، بلكه در زير كروهها

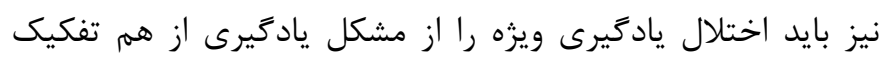

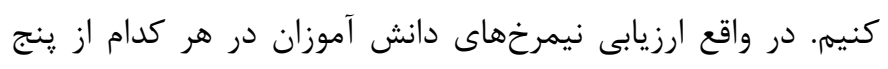

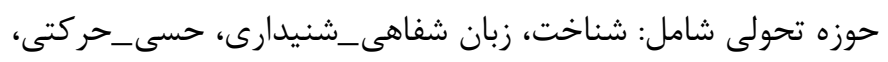

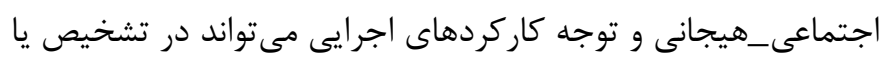

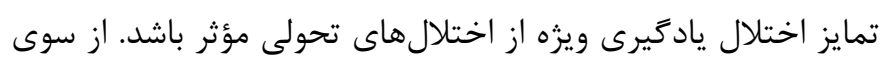

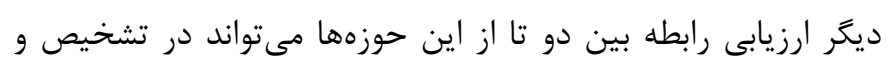

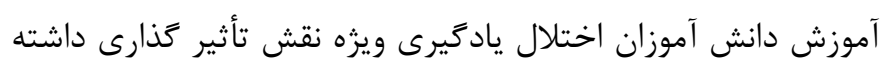

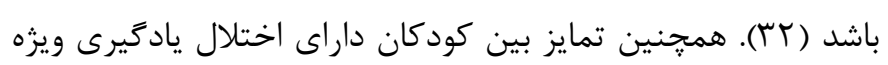

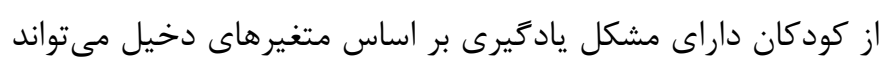

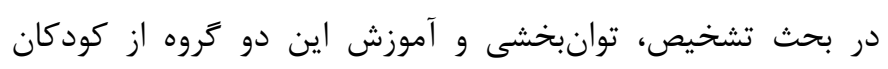

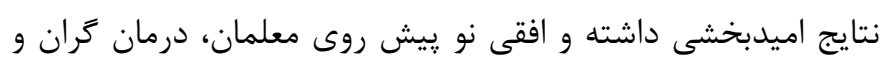

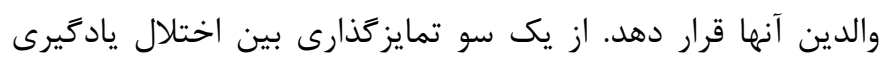

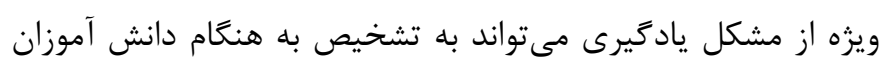

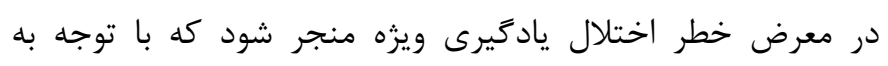

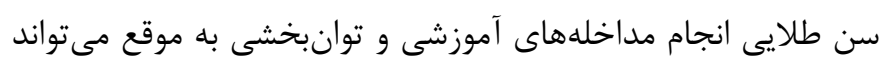

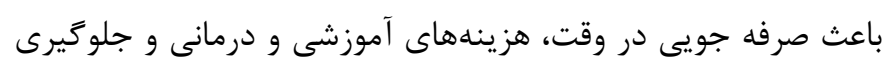

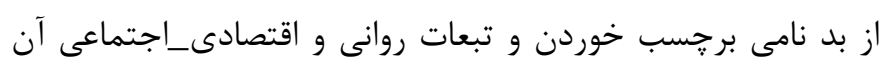

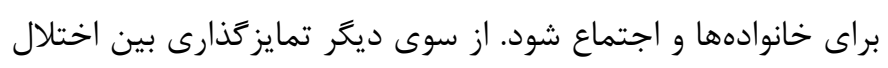

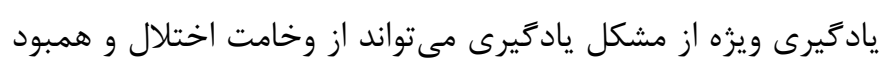

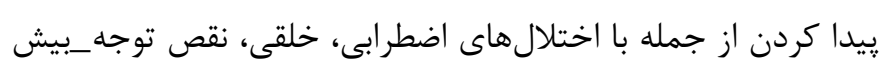

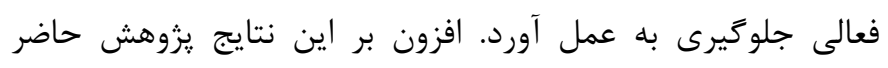

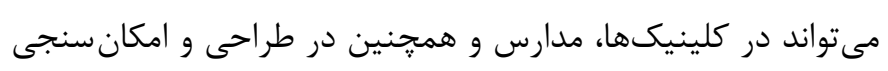

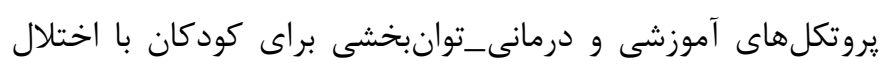

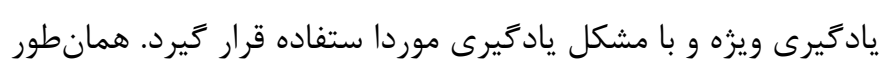

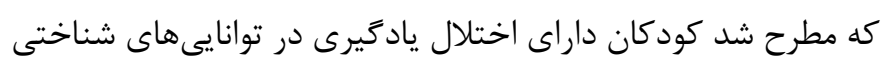

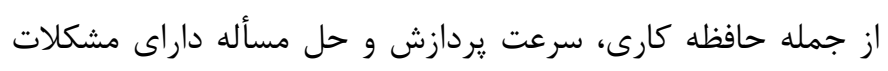

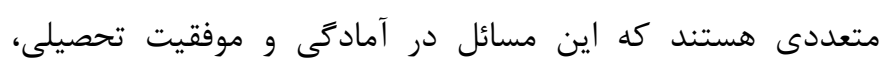

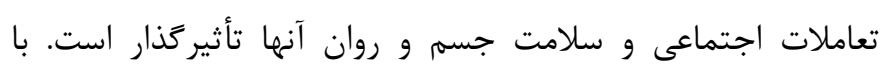

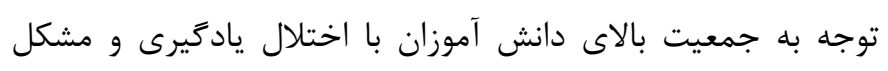

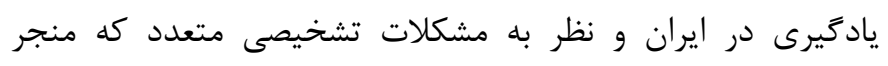

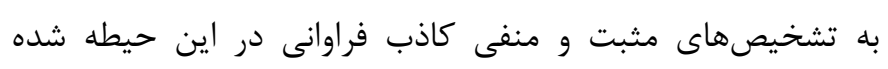

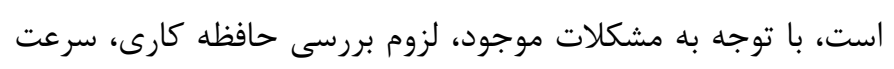

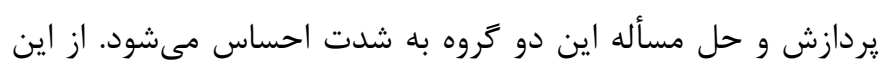

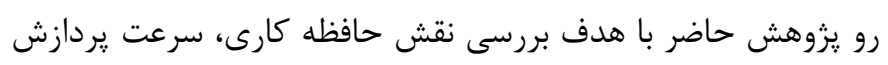

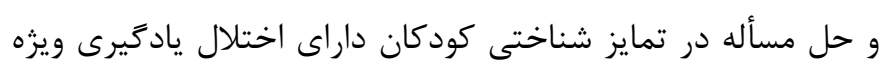
و مشكل ياد ميرى انجام ترفت.
تمركز يايدار) مورد نياز است. شواهد يزوهشى نشان مىدهد كه كودكان

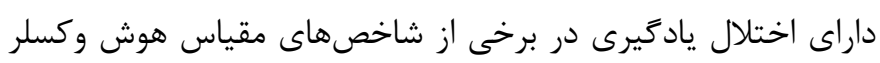
(Wechsler Intelligence Scale for Children-IV (WISC-IV)) از جمله درك كلامى و استدلال ادراكى كه در مجموع شاخص توانايى

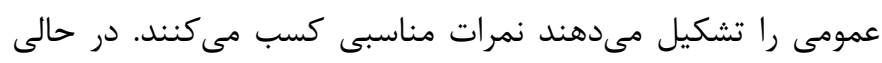

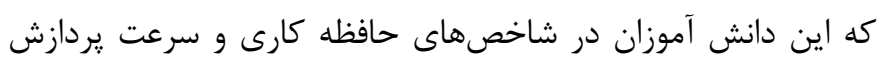

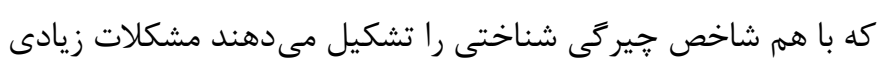

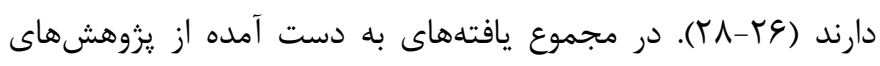

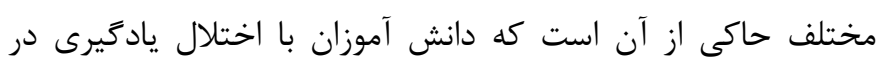

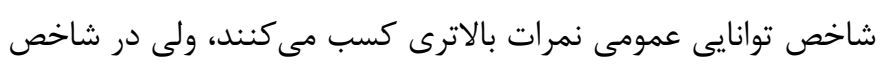
حافظه كارى و سرعت يردازش نقايص ويزماى نشان ميى ندهند. با توجه

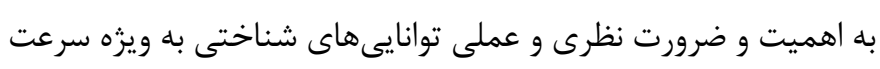

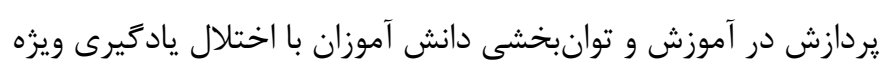

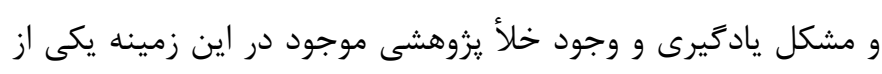

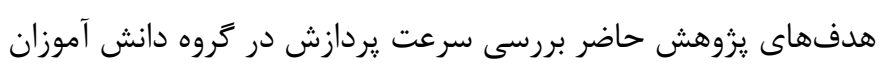

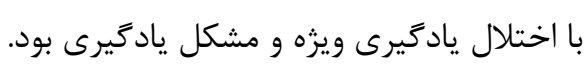

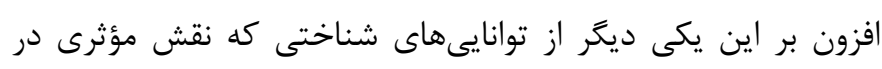

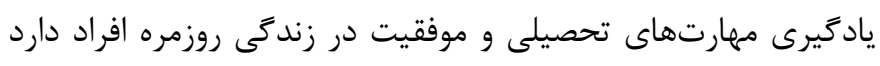

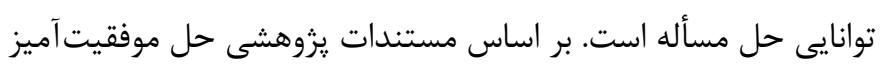

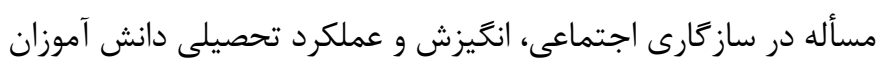

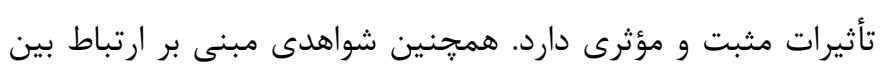

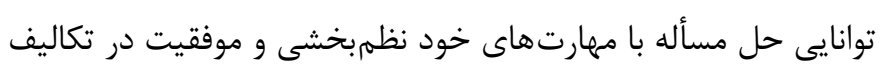
مدرسه و كاهش مشكلات ارتباطى_اجتماعى در دانش آموزان وجود داني

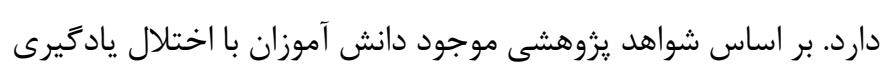

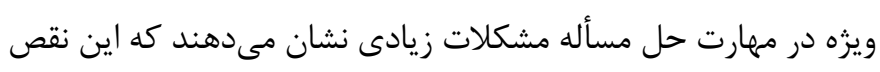

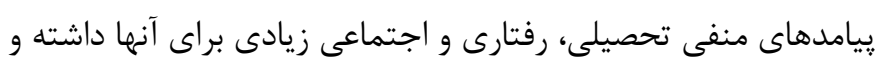

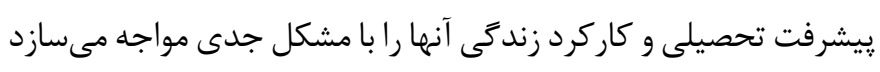

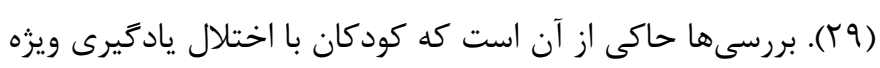

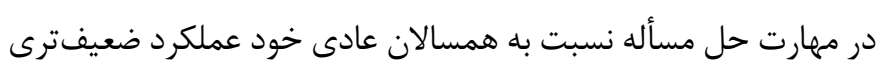

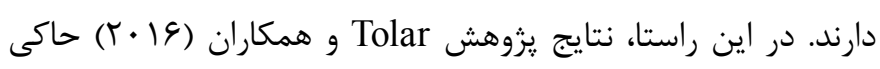

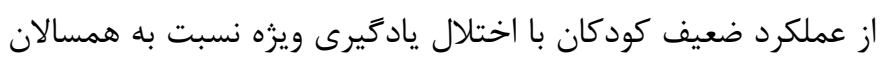

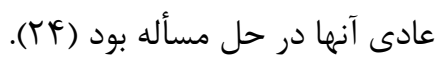

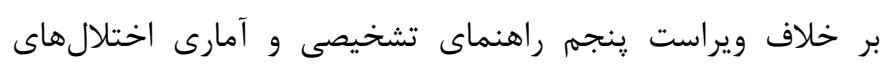

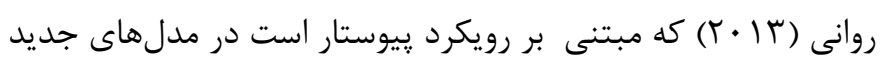

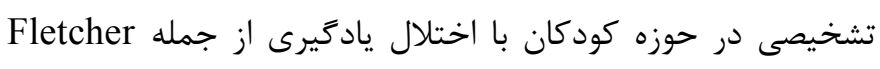

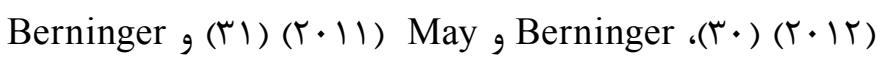

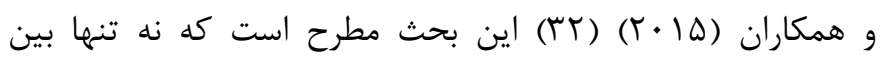


دستياران يزوهشى، استفاده از دستورالعمل اجرا و نظارت تصادفى بر

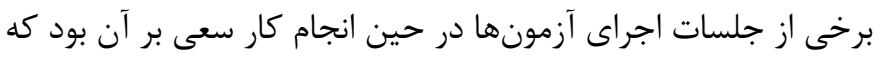

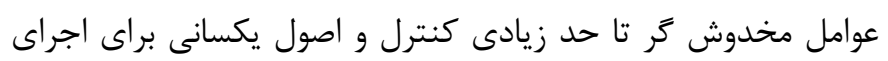

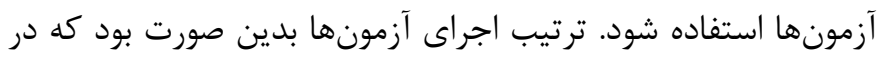

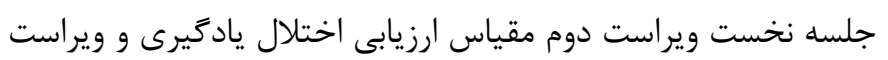

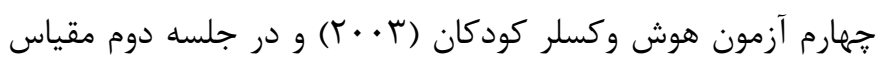

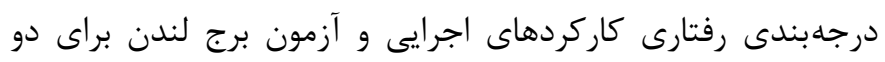

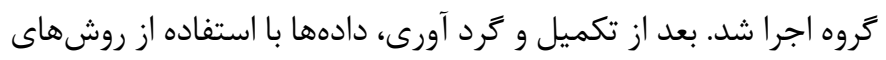
آمارى توصيفى (ميانخين و انحراف معيار) و آمار استنباطى (تحليل

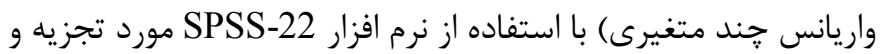

$$
\text { تحليل قرار كرفت. }
$$

مقياس ارزيابى اختلال يادگيرى-ويراست دوم The Learning) Disability Evaluation Scale-Renormed Second Edition (LDES-R2)) براى غربال كردن دانش آموزان با اختلال يادَيرى ويزه از ويراست دوم

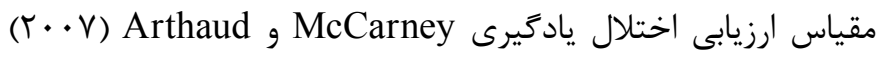

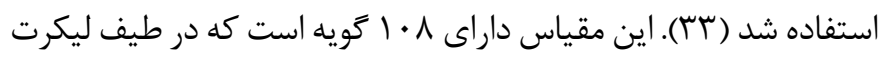
جهار درجهاى از • تا ץ (•=نامناسب براى سن از نظر تحولى، ا=هركز يا به ندرت، ب=كاهى اوقات س=اغلب اوقات يا هميشه) نمرهخذارى

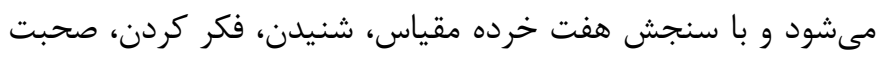

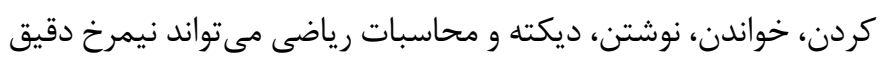

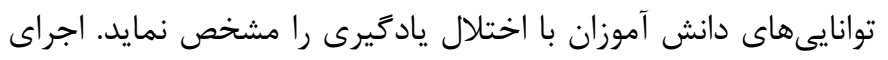

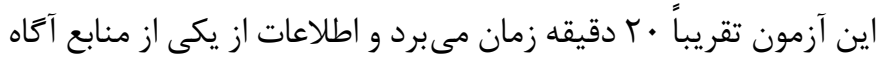

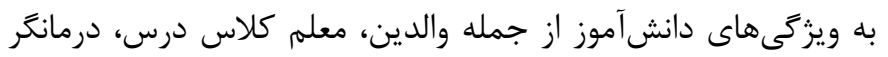

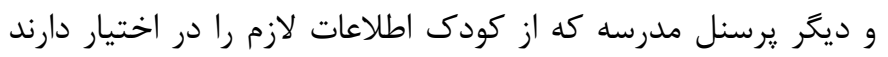
مىتواند كسب شود. هنجاريابى اين مقياس براى گروه نمونهاى شامل

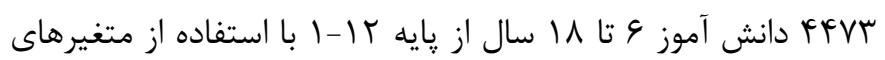

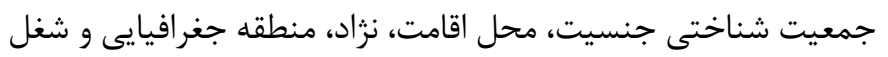

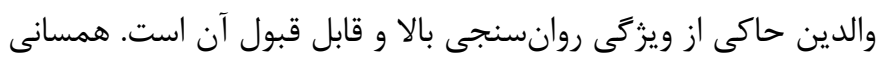

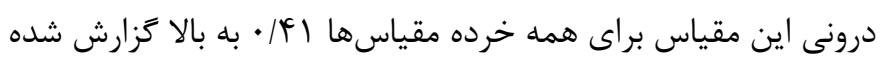

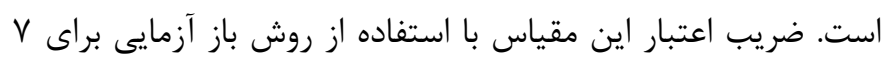

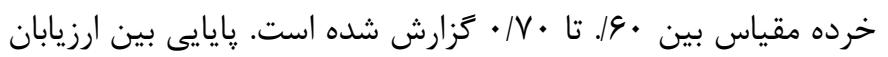

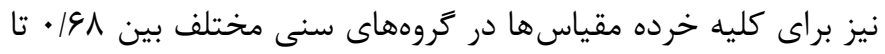

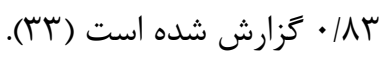
ويراست جهارم مقياس هوش وكسلر كودكان (WISC-IV): اين آزمون فرم تجديد نظر شده ويراست سوم مقياس هوش وكسلر كودكان

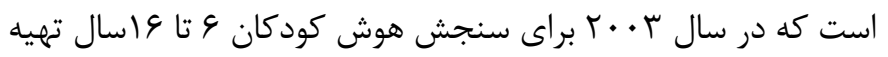

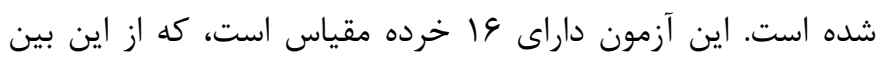

\section{روش كار}

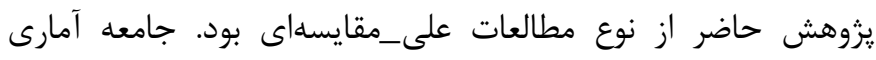

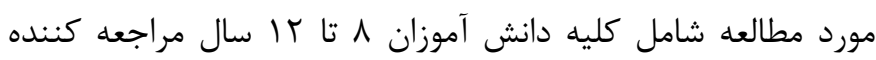

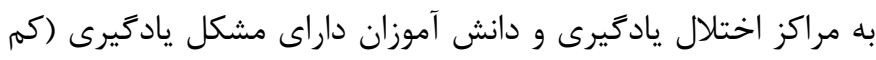

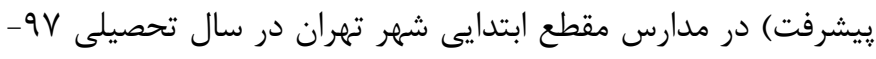

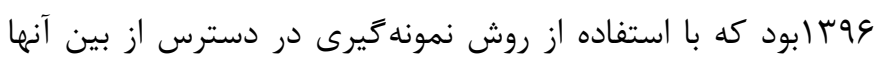

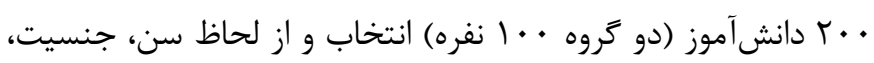

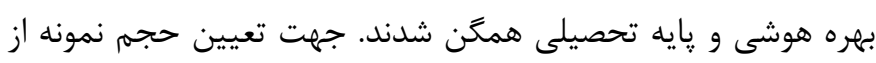

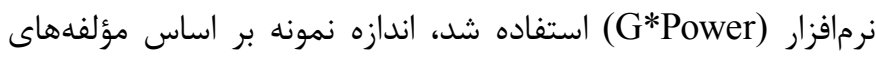

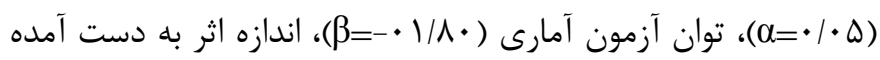

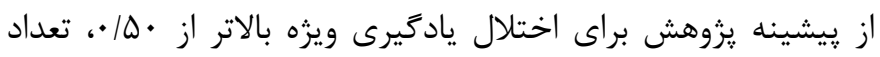

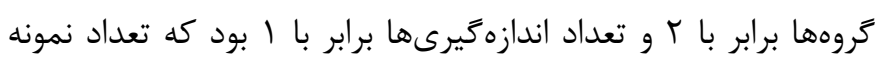

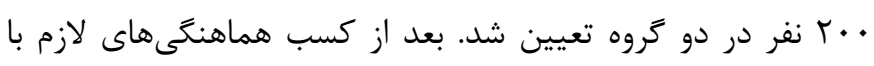
بخش يزوهش آموزش و يرورش كل شهر تهران، مجوز لازم براى ورود ندان

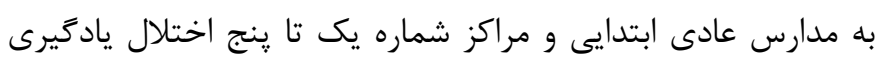

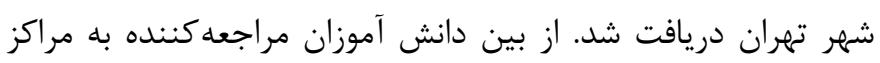

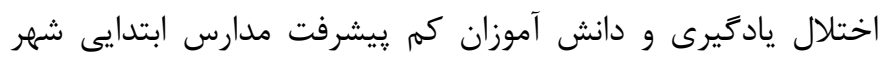

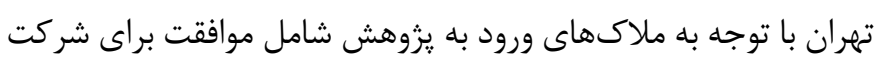

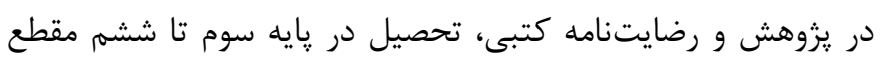

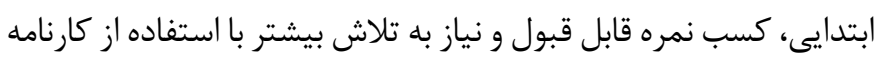

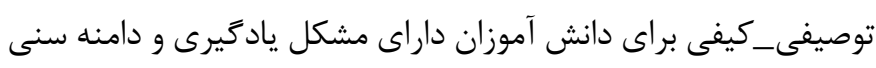

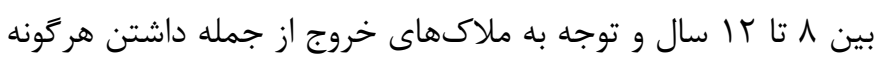

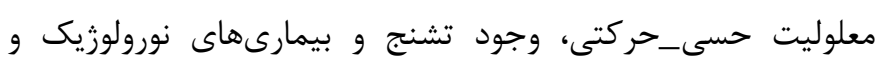

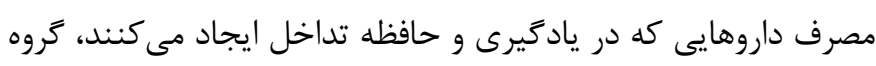

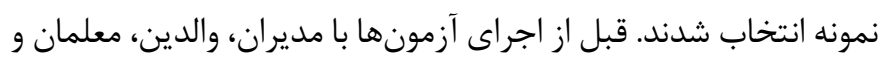

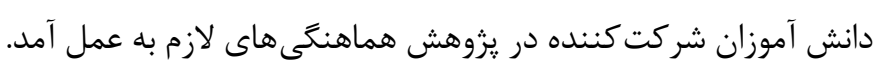

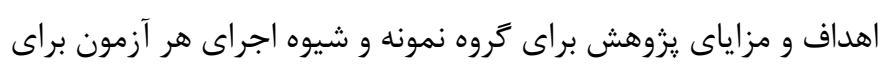

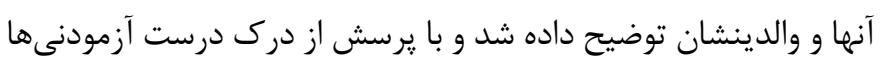

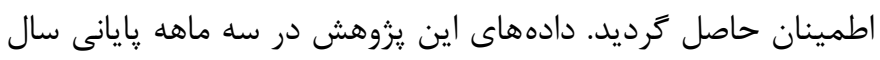

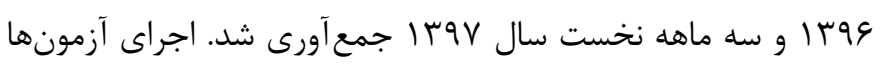

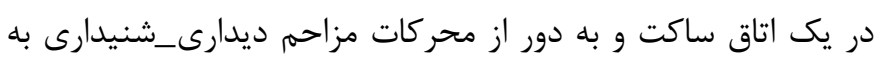

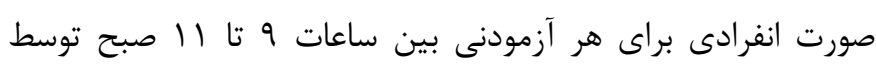

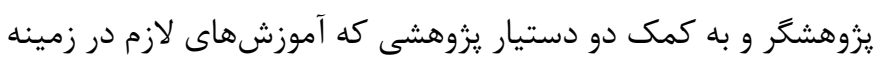
اجرا، نمرهذارى و تفسير ويراست جهارم مقياس هوش وكسلر كودكان

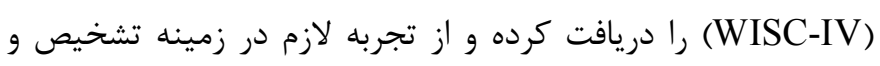
درمان كودكان داراى اختلال يادكيرى برخوردار بودند، در مراكز اختلال

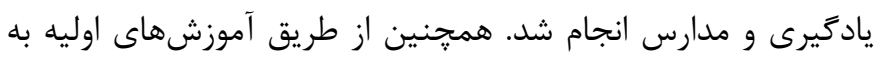




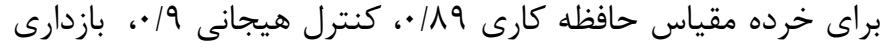

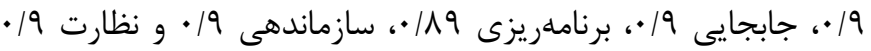

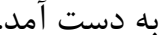

آزمون برج لندن (Tower of London test): اين آزمون در سال ra19 إبه وسيله Shallice و با هدف ارزيابى توانايى برنامه ريزى بيماران

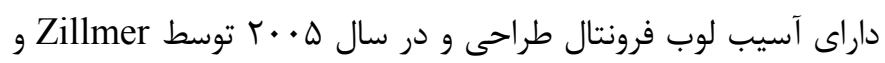

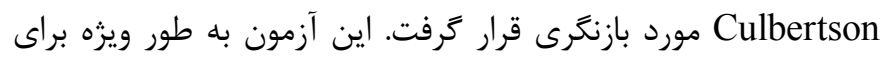
سنجش برنامهريزى و حل مسأله طراحى شده است، اما براى سنجش ساير توانايىهاى شناختى از جمله؛ انعطافيذيرى شناختى، توجه متمركز، استدلال مفهومى_انتزاعى، حافظهى كارى و رفتار قانونمدار

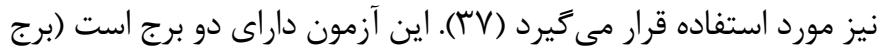

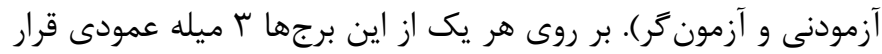

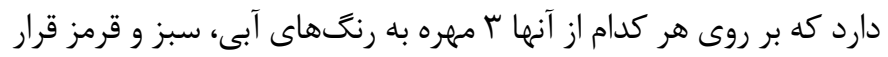

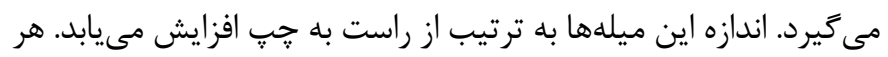

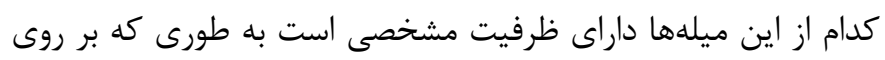

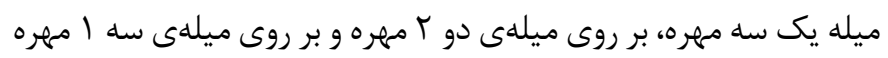

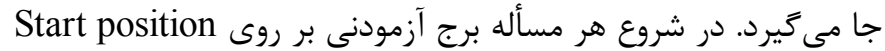
تنظيم مى

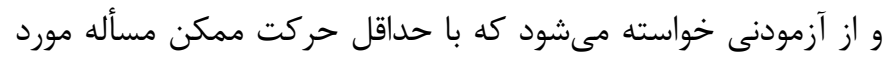

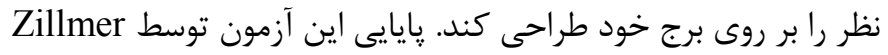

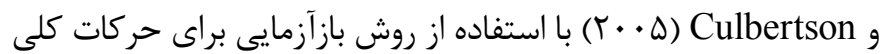

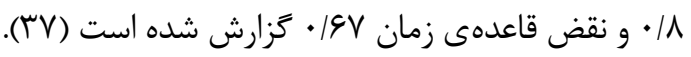

يافته ها

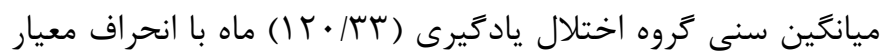

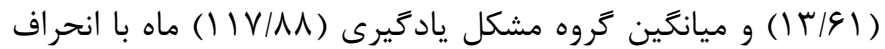
معيار (T/M/T) بود. همجنين از نمونهى انتخاب شده در كروه اختلال يادكيرى ويزه و مشكل يادكيرى بيشترين فراوانى مربوط به يايه تحصيلى سوم با \&\& و هF نفر و كمترين فراوانى مربوط به پايه تحصيلى ششم براى هر دو گروه با 9 نفر بود. افزون بر اين در

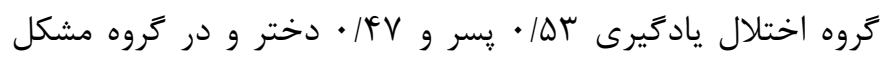

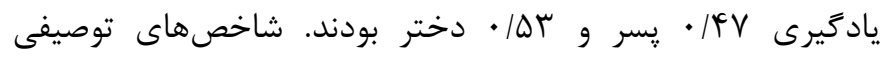

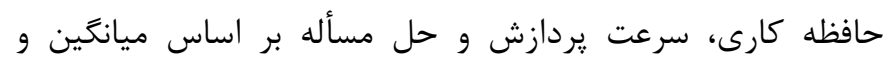

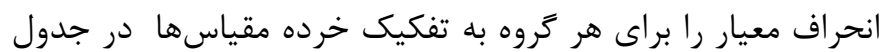
ا كزارش شده است. همانطور كه جدول ا نشان مى دهد بين ميانكَين دو كروه دانش آموزان با اختلال يادگيرى ويزه و مشكل يادگيرى در حافظه كارى،
• ا خرده مقياس (طراحى مكعبها، شباهتها، فراخناى ارقام، مفاهيم تصويرى، رمزنويسى، وازگكان، توالى حرف و عدد، استدلال تصويرى،

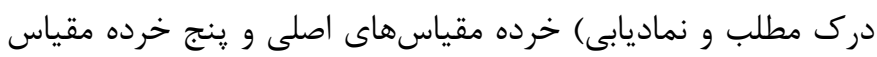
(تكميل تصاوير، خط زنى، اطلاعات عمومى، حساب و استدلال كلامى) خرده مقياسهاى تكميلى محسوب مىشوند. اين آزمون جهار نمره شاخص شامل (درك مطلب كلامى، استدلال ادراكى، حافظهى كارى، سرعت يردازش و هوشبهر كل) را فراهم مى كند. صادقى و همكاران

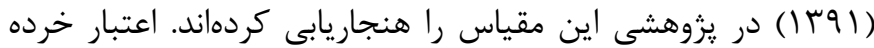

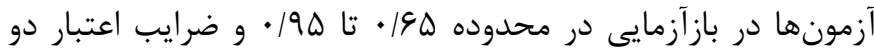

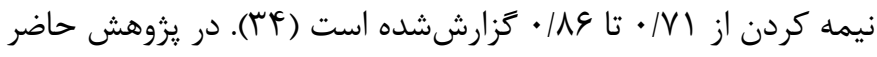
از دو خرده مقياس فراخناى ارقام و توالى حرف و عدد استفاده شد، اين

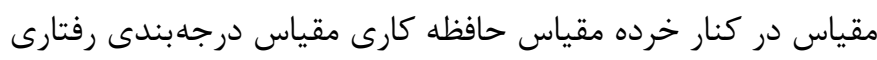

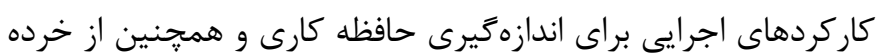
مقياسهاى رمزنويسى و نماديابى براى اندازهكيرى سرعت يردازش

كودكان داراى اختلال يادگيرى و مشكل يادَيرى استفاده گرديد. مقياس درجهبندى رفتارى كاركردهاى اجرايى Behavioral) Rating Scale of Executive Functions Gioia سنجش كاركردهاى اجرايى كودكان و نوجوانان هـ تا ل1 سال در محيط

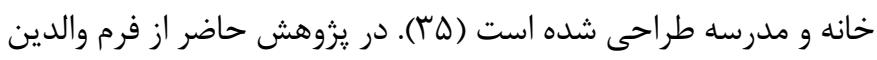

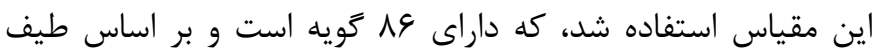
سه كزينهاى ليكرت هيج وقت (•)، كاهى اوقات (1) و هميشه (r) IVT نمره گذارى مىشود. بالاترين نمرهاى كه فرد مىتواند كسب كند و كمترين نمره صفر است و هرجه نمره آزمودنى بيشتر باشد حاكى از عملكرد يايين و ضعف در كاركردهاى اجرايى است. اين مقياس شامل هشت خرده مقياس بازدارى، جابجايى، كنترل هيجانى، آغاز

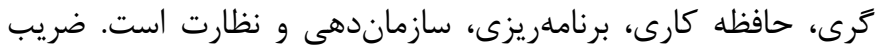

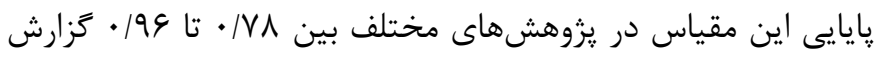

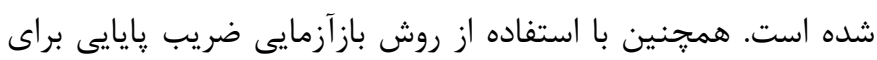

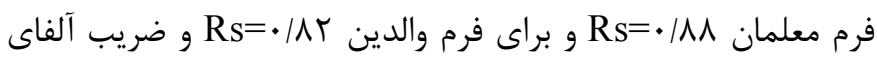

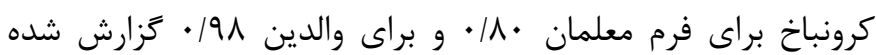

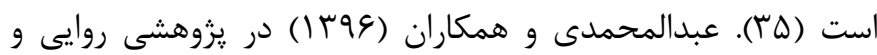
اعتبار فرم والدين اين يرسشنامه را با استفاده از ضريب آلفاى كرونباخ براى خرده مقياسهاى بازدارى، جابجايى، كنترل هيجانى، آغازگرى،

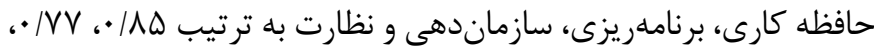

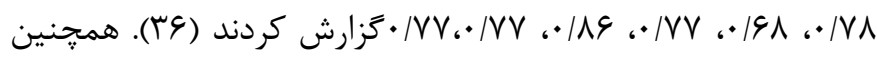

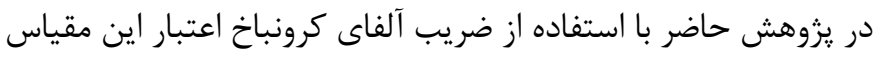


واريانس جند متغيرى (MANOVA) استفاده شده است. همجنين سرعت ״ردازش و مهارت حل مسأله تفاوتهايى وجود دارد، اما به سبب نابرابرى ميانگينها و دامنه تغييرات نمرات در متغيرها، در جهت تعديل كشيدگى توزيع نمرات خام و قابل مقايسه بودن آنها در دو گروه، نمرات به نمره استاندارد Z تبديل شدندكه نتيجه آن در شكل ارائه شده است. اين كه اين تفاوتها از حد شانس و تصادف بالاتر مىرود يا نه، بر ما مشخص نيست، به منظور آزمون اين تفاوتها، با توجه به وجود جند متغير وابسته با سطح اندازه گيرى حداقل فاصلهاى و دو گروه دانش آموزان با اختلال يادگيرى و مشكل يادگيرى از آزمون تحليل

جدول ا. شاخصهاى توصيفى حافظه كارى، سرعت يردازش و حل مسأله به تفكيك گروهها

گ

\begin{tabular}{|c|c|c|c|}
\hline مشكل يادگيرى & اختلال يادگيرى ويثه & زير مقياس & متغير \\
\hline ميانكين土|نحراف استاندارد & ميانگين土|نحراف استاندارد & & \\
\hline$r / \Delta \mid \pm 9 / 9 \Lambda$ & $r / g \varphi \pm|r /| \mid$ & حافظه كارى BRIEF & \multirow{3}{*}{ حافظه كارى } \\
\hline$r / 91 \pm 1 r / 99$ & $|/| \Delta \pm 1 / / \Delta \Lambda$ & فراخناى ارقام & \\
\hline$p / r q \pm q / \Delta \wedge$ & $1 / F \wedge \pm \Lambda / T F$ & توالى حرف و عدد & \\
\hline$q / \Lambda F \pm r \mid / \Delta)$ & $r / q r \pm r q / r r$ & رمزنويسى & \multirow{2}{*}{ سرعت يردازش } \\
\hline$\varphi / r r \pm|q| \wedge \varphi$ & $r / V q \pm 1 r / f q$ & 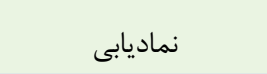 & \\
\hline $1 / T V \pm r / Q$ & $|/ r \Delta \pm r / r|$ & تعداد مسأله درست & \multirow{2}{*}{ حل مسأله } \\
\hline$q r / \cdot q \pm r \cdot v / r$. & $1 \cdot \Delta / 99 \pm T K F / K T$ & زمان كل & \\
\hline
\end{tabular}

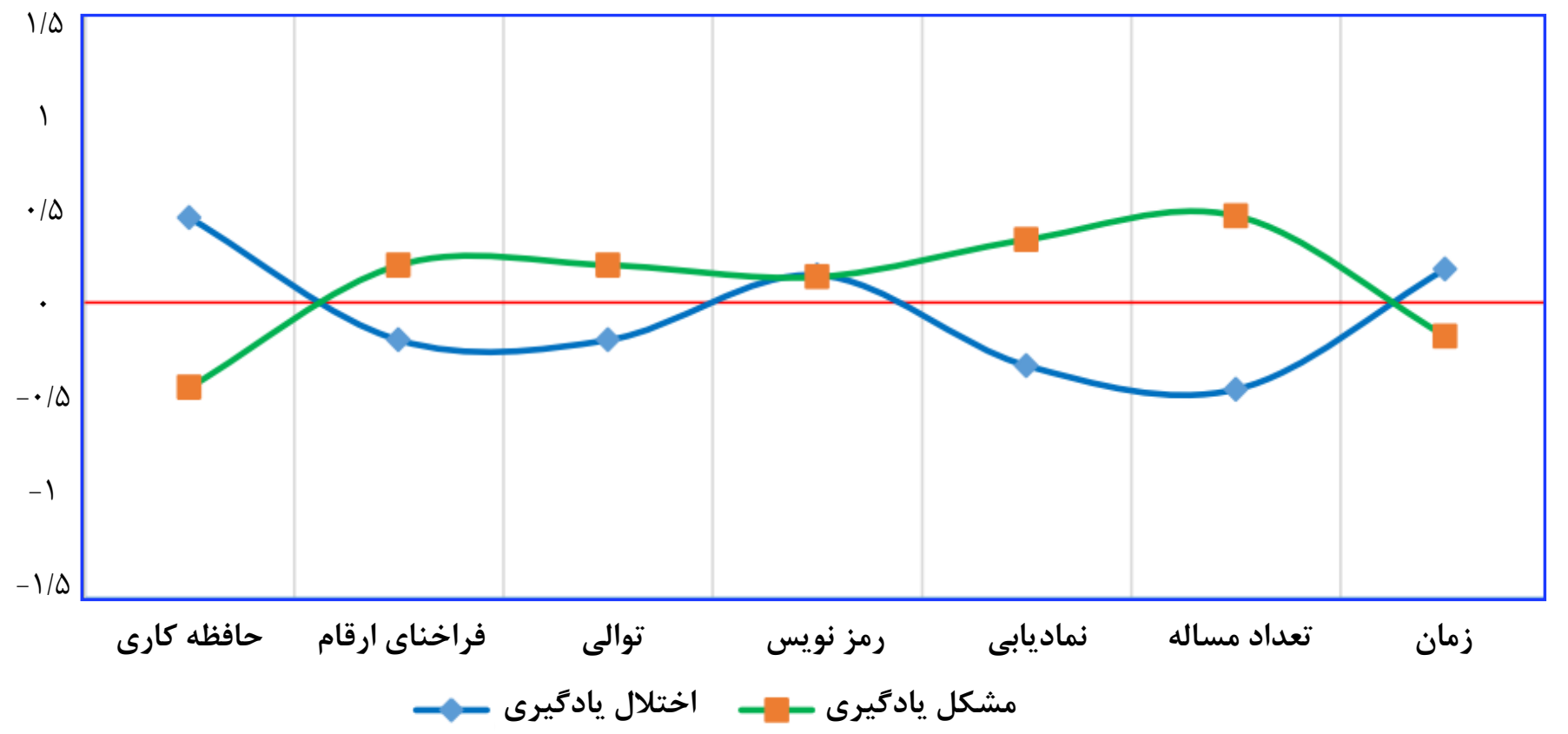

شكل ا. عملكرد كلى دو كروه در متغيرهاى حافظه كارى، سرعت يردازش و حل مسأله 
جدول r تزارش شده است. همانطور كه نتايج تحليل واريانس جند متغيرى در جدول r نشان مىدهد در حافظه كارى بين دو گروه در خرده مقياسهاى حافظه كارى BRIEF، فراخناى ارقام و توالى حرف و عدد تفاوت معنادارى درى درى درده

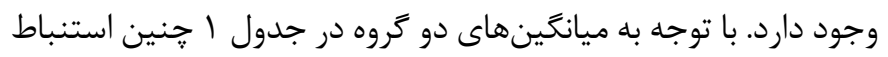

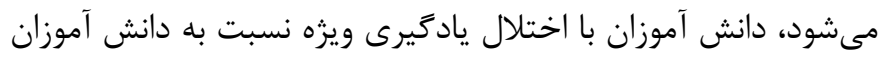
با مشكل يادَيرى در حافظه كارى از عملكرد ضعيفترى برخوردارند. همجنين بر اساس يافتههاى به دست آمده در سرعت يردازش بين دو داريط كروه در خرده مقياسهاى رمزنويسى و نماد يابى، تفاوت معنادارى

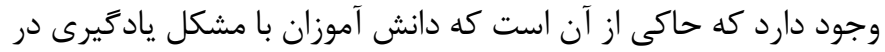
سرعت يردازش نسبت به دانش آموزان با اختلال يادگيرى ويزه عملكرد بهترى داشتند. افزون بر اين نتايج تحليل واريانس جند متغيرى نشان

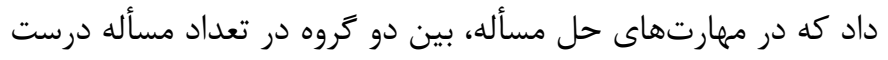
و زمان كل تفاوت معنادارى وجود دارد. در واقع بر اساس يافتههاى

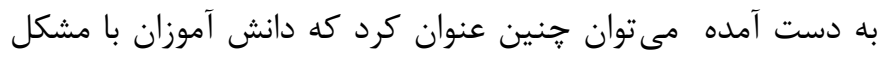
يادَيرى در مهارتهاى حل مسأله نسبت به دانش آموزان با اختلال يادكيرى ويزه از وضعيت بهترى برخوردارند.
ييش از انجام آزمون تحليل واريانس جند متغيرى لازم بود كه از ييش فرضها، نرمال بودن توزيع نمرات و همخنى واريانسها آحاه باشيم كه به آنهائ اين منظور جهت آزمون نرمال بودن نمونه از آزمون كالموكروف_اسميرنف

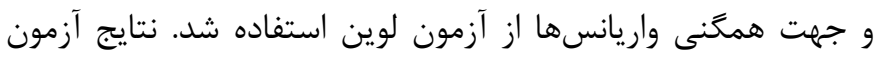
كالموكروف_اسميرنف نشان داد كه كجى و كشيدگى در متغيرهاى

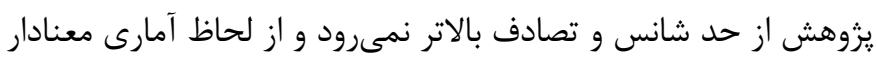

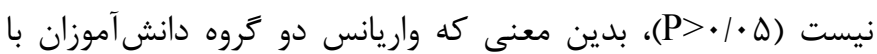
اختلال يادكيرى ويزه و مشكل يادگيرى تفاوت معنادار و بالاتر از حد شانس و تصادف را نشان نمىدهند؛ بنابراين شرط نرمال بودن توزيع متغيرهاى يزوهش برقرار است. همجنين نتايج آزمون لوين نشان داد كه شرط برابرى واريانسهاى بين گروهى رعايت شده و ميزان واريانس تران

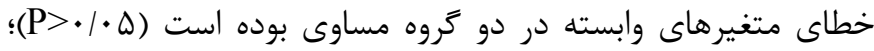

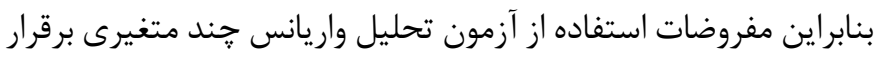

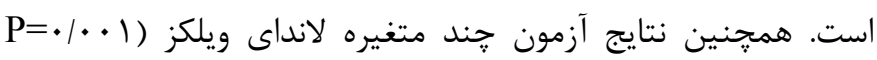

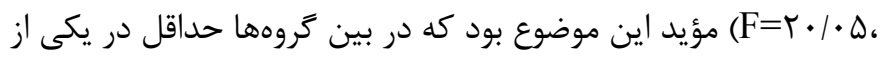
متغيرهاى وابسته تفاوت معنادارى وجود دارد كه براى بررسى اين امر بر برد از آزمون تحليل واريانس خهند متغيرى استفاده شد، كه نتايج آن در

جدول ז. آزمون تحليل واريانس جند متغيرى براى تعيين تفاوت بين كروهى در متغيرهاى مورد مطالعه در يزوهش

\begin{tabular}{|c|c|c|c|c|c|c|c|}
\hline مجذور اتا & $\mathbf{P}$ & $\mathbf{F}$ & مجذانگين & درجه آزادى & مجذورات & منبع & متغير \\
\hline \multirow[t]{2}{*}{$\cdot / 11$} & $.1 \cdot \cdot 1$ & Fo/GG & $\Delta \Lambda V / T V$ & 1 & $\Delta \Lambda V / T V$ & كروه & \multirow{2}{*}{ حافظه كارى BRIEF } \\
\hline & & & $I T / A$. & 191 & $r \Delta r \Delta / \Delta \Delta$ & خطا & \\
\hline \multirow[t]{2}{*}{.1 .9} & $.1 \cdot \cdot 1$ & IT/QT & $91 / 9$. & 1 & $91 / 9$. & كروه & \multirow{2}{*}{ فراخناى ارقام } \\
\hline & & & $4 / 91$ & 191 & QYT/VD & خطا & \\
\hline \multirow[t]{2}{*}{$\cdot / \cdot r$} &.$/ \cdot 1$ & V/AT & Vब|A & 1 & VG/A & تروه & \multirow[b]{2}{*}{ توالى حرف و عدد } \\
\hline & & & س & 191 & $r \cdot g F / \lambda$. & خطا & \\
\hline \multirow[t]{2}{*}{$\cdot / \cdot r$} & $.1 \cdot 1$ & ए/१६ & rrq/A. & 1 & rrq/A. & تروه & \multirow{2}{*}{ ر رزنويسى } \\
\hline & & & rr/qT & 191 & $119 \wedge \mathrm{N} / \mathrm{V} \Delta$ & خطا & \\
\hline \multirow[t]{2}{*}{$\cdot / 11$} & $\cdot 1 \cdot \cdot 1$ & $T F / I G$ & $\Delta \vee N / \cdot \cdot$ & 1 & $\Delta \vee \Lambda / \cdot \cdot$ & كروه & \multirow{2}{*}{ ن } \\
\hline & & & IY/AG & 191 & FVrG/A & خطا & \\
\hline \multirow[t]{2}{*}{$\cdot / r}$. & $.1 \cdot .1$ & $4 q / 1$. & $\Lambda \Delta / r \Delta$ & 1 & $\Lambda \Delta / r \Delta$ & تروه & \multirow{2}{*}{ تعداد مسأله درست } \\
\hline & & & $1 / N r$ & 191 & TFr/Dq & خطا & \\
\hline \multirow[t]{2}{*}{$\cdot / \cdot r$} & $\cdot / \cdot 1$ & $\varepsilon|\Delta|$ & द9. rV/\&D & 1 & $99 . r V / \varepsilon \Delta$ & كروه & \multirow{2}{*}{ زمان كل } \\
\hline & & & $1 \cdots p q / \mu q$ & 191 & $191 \vee 9.119$ & خطا & \\
\hline
\end{tabular}


اجتماعى هيجانى آنها را دجار مشكلات زيادى كرده است.

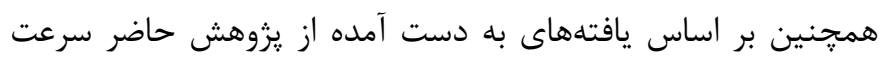

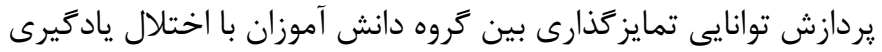
ويزه از گروه دانش آموزان با مشكل يادَيرى را دارد. بر اساس ناس نتايج

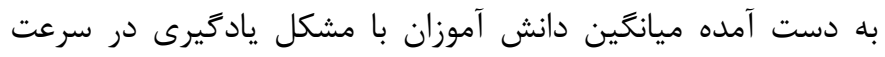

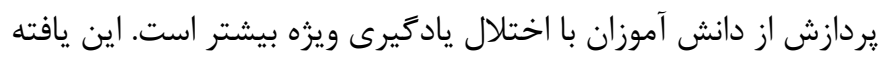

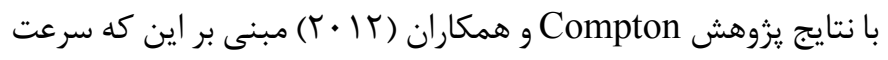

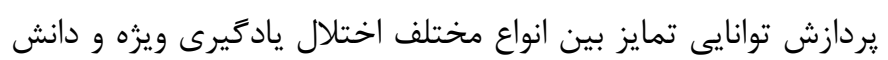

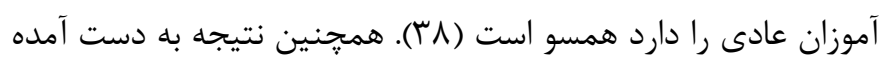

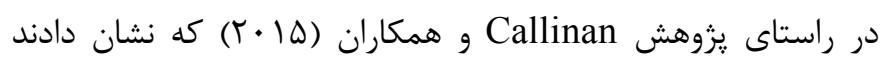
يردازش واج شناختى، سرعت ناميدن و حافظه كارى توانايى يِيش بينى

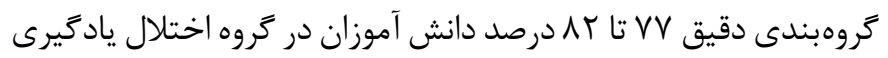

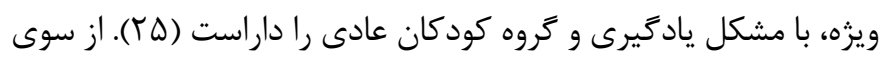

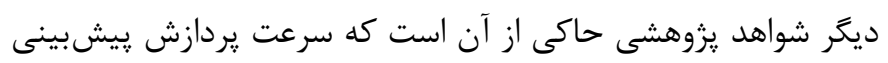

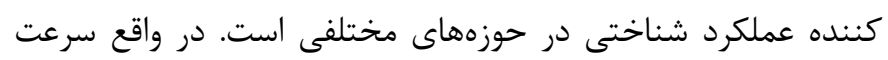

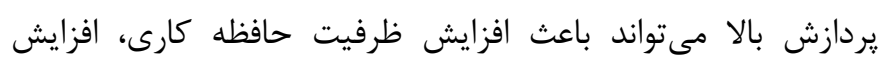

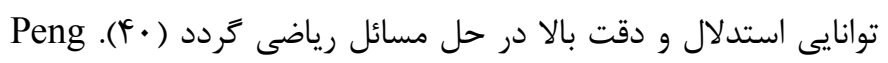

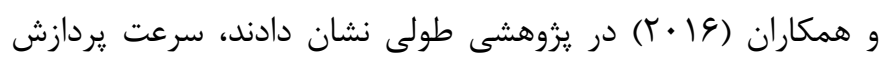

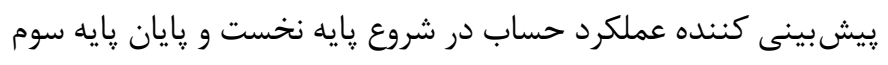

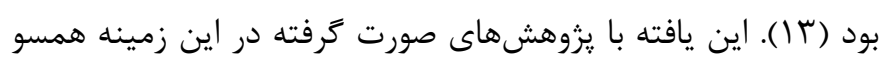

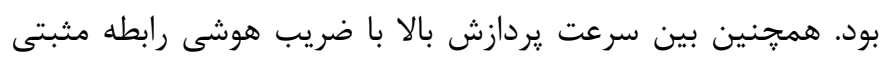

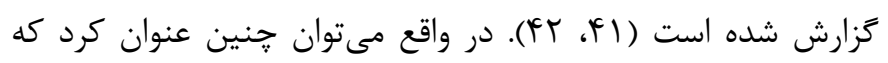

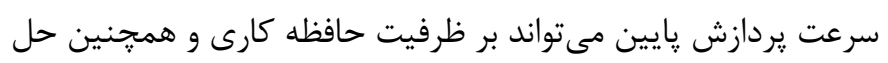

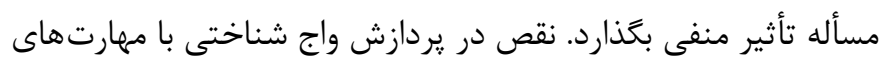

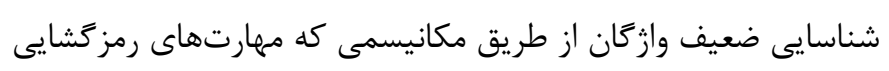

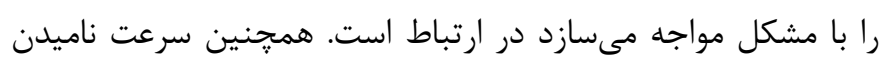

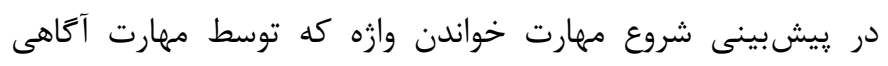

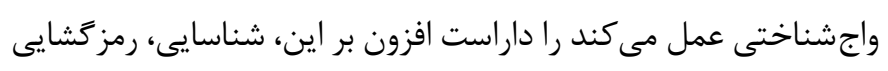

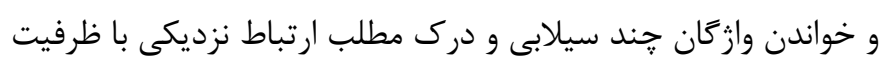

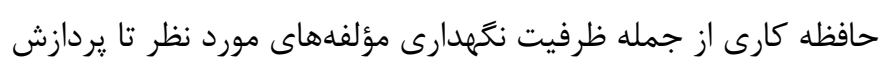

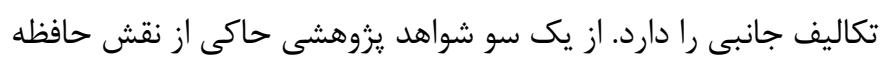

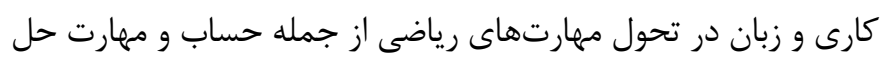

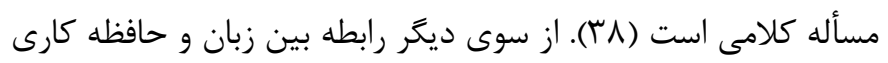
مى تواند دليل ضعف در سرعت يردازش باشد.

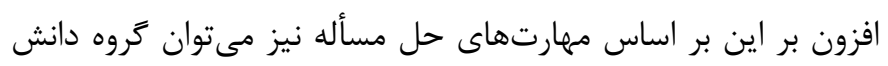

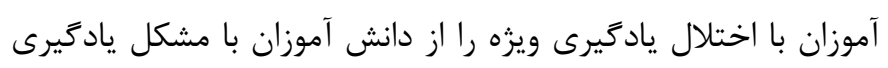

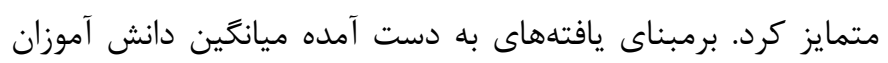

يزوهش حاضر با هدف بررسى نقش حافظه كارى، سرعت يردازش و

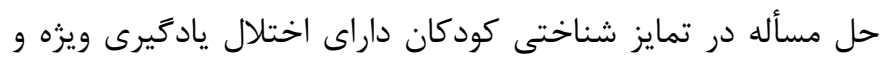

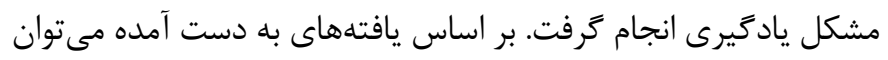

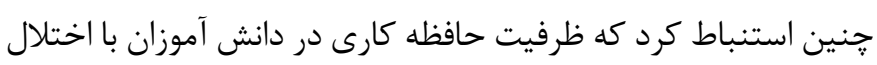

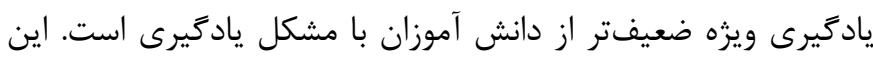

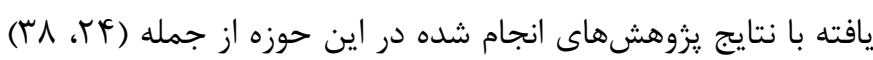

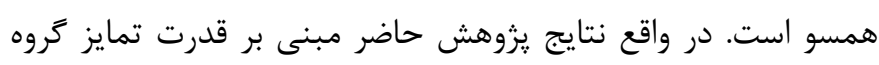

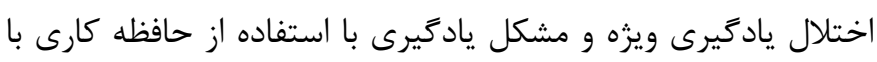

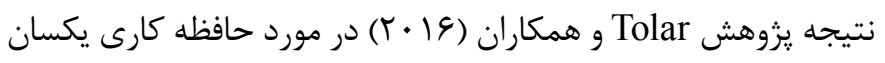

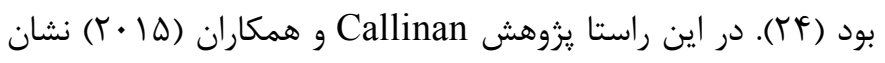

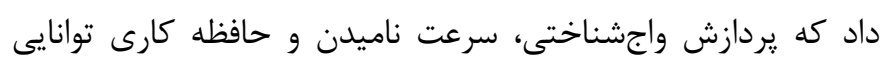

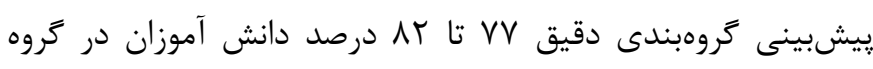

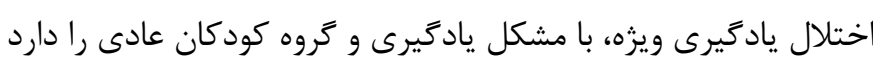

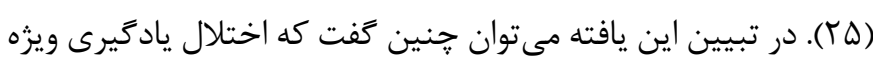

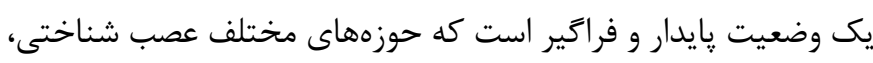

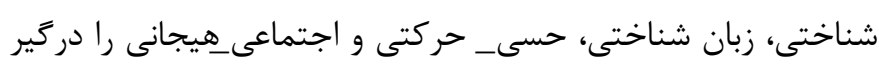

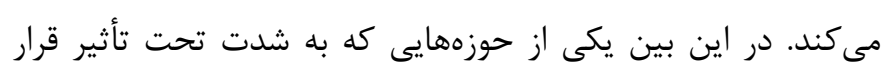

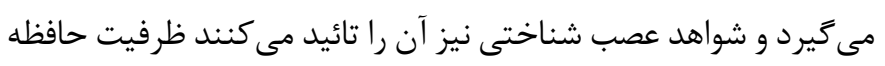

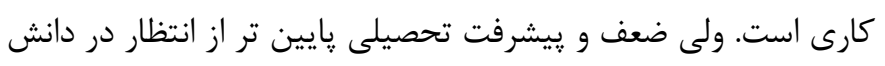

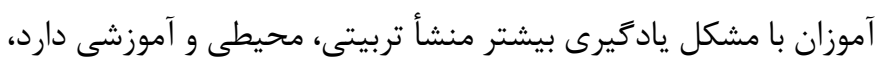

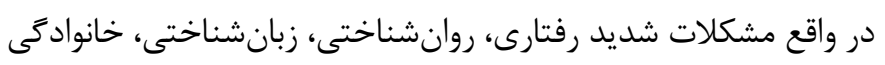

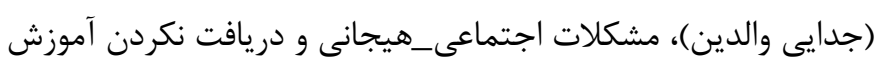

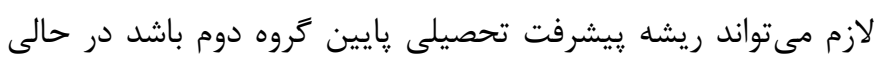

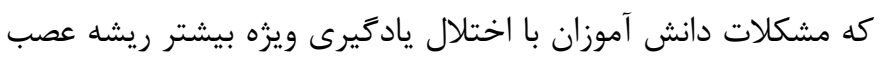

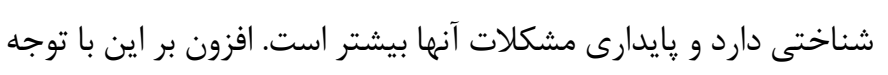

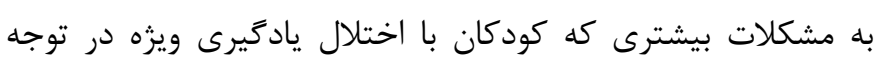

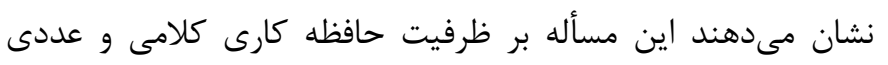

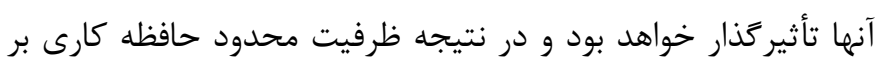

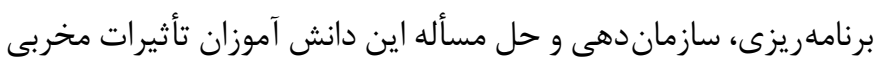

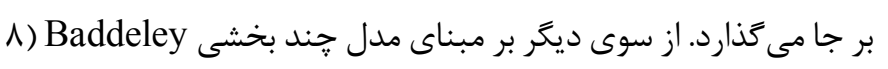

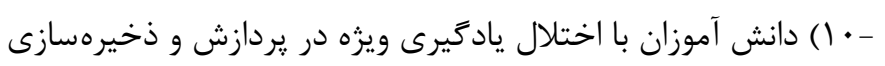

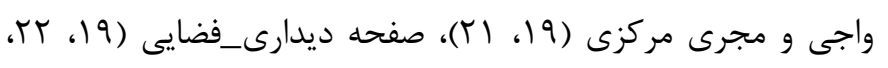

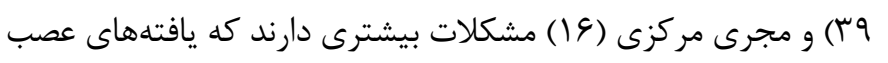

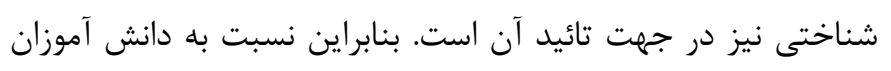

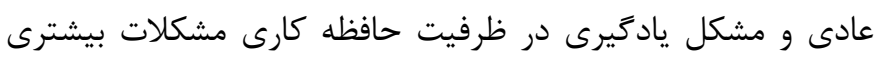
نشان مىدهند كه نتيجه اين ضعف در حوزههاى مختلف تحصيلى و وريت 
حافظه كارى است. هر هند كه براى موفقيت تحصيلى و يادگيرى در

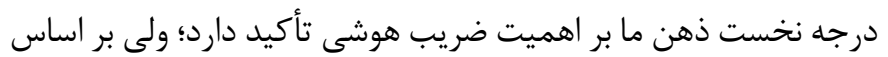
مستندات يزوهشى حافظه كارى مهمترين بيش بينى كننده موفقيت

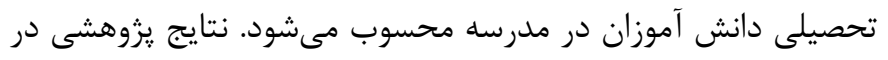

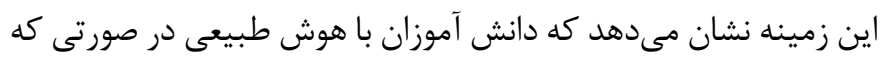

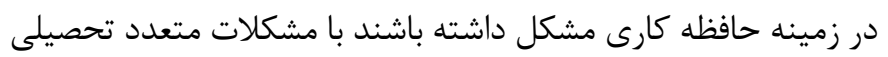
مواجه و دانش آموزان باهوش پايينتر در صورت داشتن حافظه كارى كارآمد از يیشرفت تحصيلى بالاترى نسبت به آنها برخوردارند. پيشينه كارى يزوهشهاى انجام شده در اين زمينه حاكى از ارتباط بين حافظه كارى و وِيشرفت تحصيلى بعد از كنترل آمارى ضريب هوشى دانش

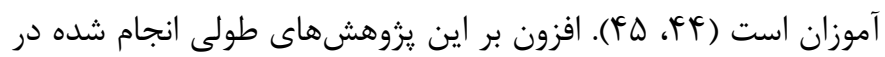

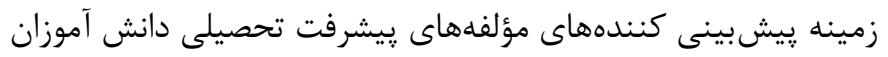

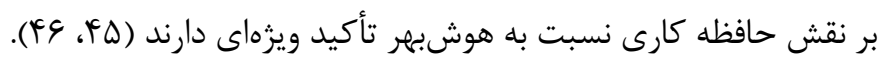

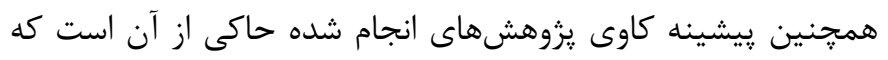

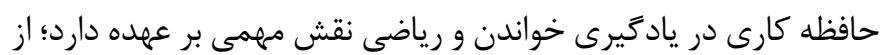

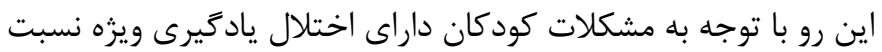
به كودكان داراى مشكل يادكيرى ضعف در حافظه كارى به صورت محسوس بر ويشرفت تحصيلى آنها تأثيرات مخربى بر جا مى كذارد. در واقع نتايج يروهش حاضر به وضوح به نقش و اهميت بالاى حافظه

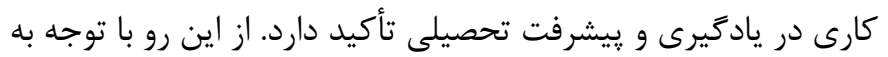
اثرات انكارنايذير حافظه كارى و اثرات كمتر ضريب هوشى بر بيشرفي

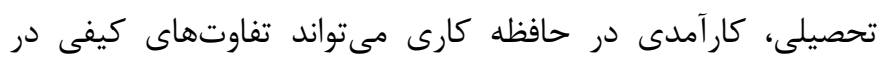

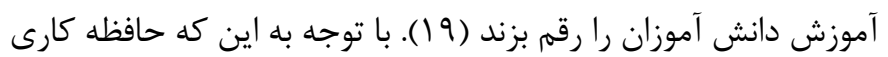

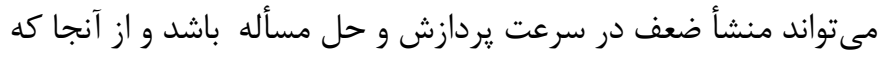
نقصهاى يردازشى در دانش آموزان با اختلال يادگيرى ويزه در اغلب دران موارد به نقص در حافظه كارى و سرعت يردازش مرتبط است، از اين رو توجه به يافتههاى به دست آمده در يزوهش حاضر مىتواند كاربردهاى

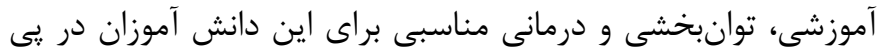

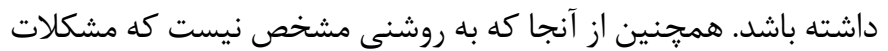

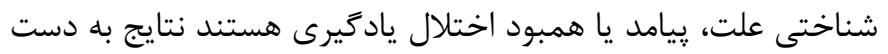

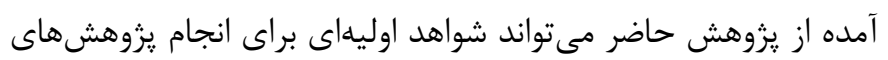

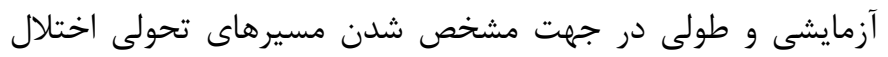

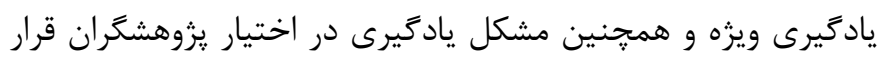

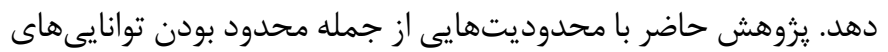
شناختى مورد بررسى به حافظه كارى، سرعت يردازش و حل مسأله بود.

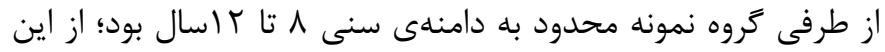
رو يِشنهاد مىشود كه در يزوهشهاى آتى يزوهشكَران به كروههاى
با اختلال يادكيرى ويزه در تعداد مسأله-هاى درست پايينتر و در زمان كل بيشتر از دانش آموزان با مشكل يادگيرى بود. اين يافته با باديا

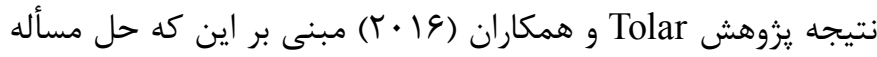

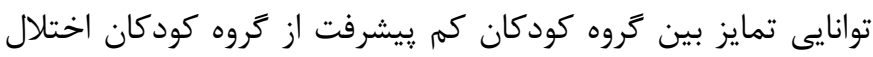

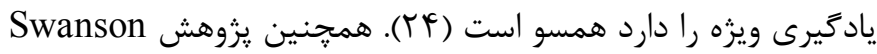

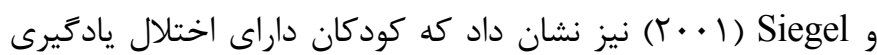

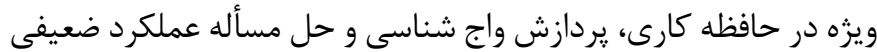
نشان مىدهند (Y ( ). در واقع بر اساس شواهد يزوهشى دانش آموزان با اختلال يادگيرى ويزه در انتخاب بهترين راه حل در موقعيتهاى اجتماعى و تحصيلى ضعفهايى دارند و معمولاً هدف و راه حلهايى را براى حل مسائل انتخاب مى كنند كه يُيامدهاى مناسبى براى آنها در

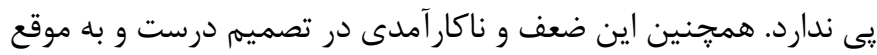
و حل درست مسائل باعث مىشود كه اين كودكان از سوى همسالان ندان

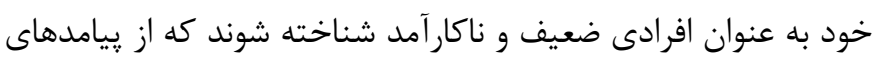

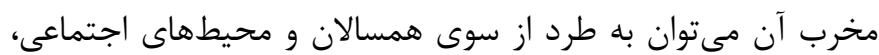
انزوا، كاهش اعتماد به نفس، عزتنفس و خودكارآمدى يايين اين دانش آموزان اشاره كرد. از سوى ديخر ضعف در مهارتهاى حل مسأله مىتواند واكنشى از سوى اين كودكان به شرايط بد اجتماعى و ديدكاه

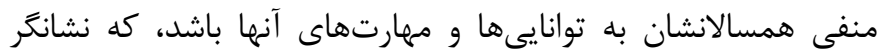
يذيرفته نشدن، طرد از سوى همسالان، نعاه منفى اجتماع به اين افراد

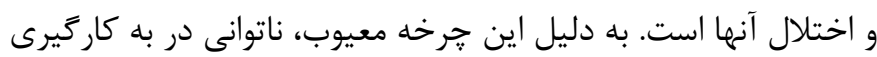

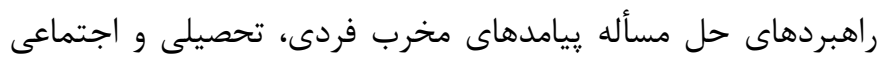

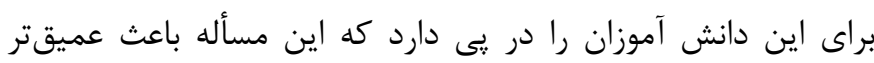

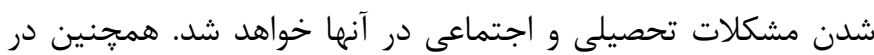
تبيين اين يافته مىتوان عنوان كرد كه ضعف در حافظه كارى مىتواند بيامدهاى منفى و مشكلات تحولى در حل مسأله دانش آموزان از جمله

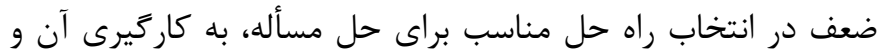

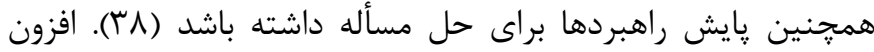
بر اين، سرعت گردازش پايين در دانش آموزان با اختلال يادكيرى

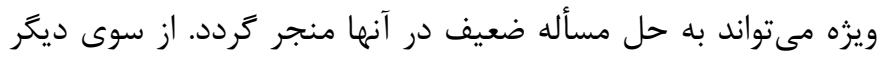

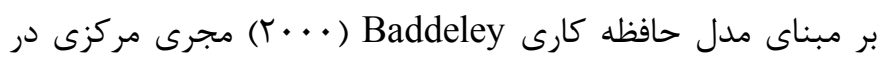

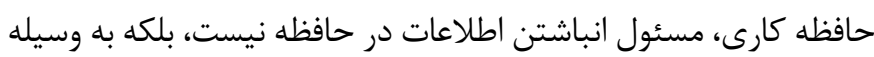

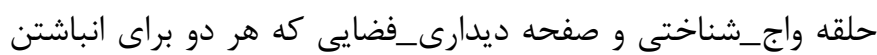
اطلاعات كلامى و غير كلامى است حمايت مىشود. نقص در كاركردهاى اجرايى مركزى و حلقه واج شناختى ارتباطى نزديك با عملكرد ضعيف

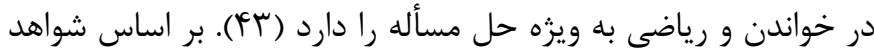
بروهشى عامل اصلى براى موفقيت و پِيشرفت تحصيلى دانش آموزان 


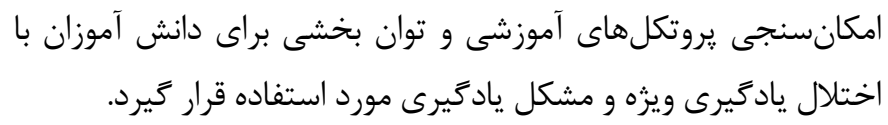

\section{تشكر و قدرداذى}

يزوهش حاضر بركرفته از رساله دكترى نويسنده نخست يزوهش

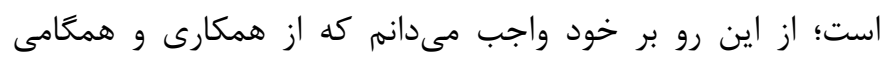
صميمانه همهى دانش آموزان شركت كننده در اين يزوهش و نيز از كليه والدين، معلمان، مديران و يرسنل مدارس عادى و مراكز اختلال يادگيرى شهر تهران نهايت سياس و قدردانى را داشته باشم. افزون

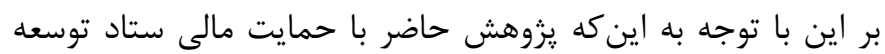

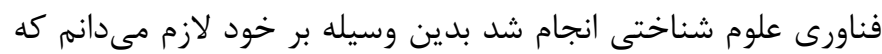

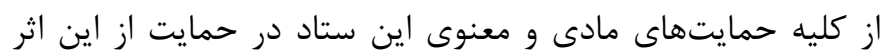
نهايت سياس را نيز داشته باشم.

\section{References}

1. Association AP. Diagnostic and statistical manual of mental disorders (DSM-5®). Arlington VA:American Psychiatric Pub;2013.

2. Casey J. A model to guide the conceptualization, assessment, and diagnosis of nonverbal learning disorder. Canadian Journal of School Psychology. 2012;27(1):35-57.

3. Poletti M, Carretta E, Bonvicini L, Giorgi-Rossi P. Cognitive clusters in specific learning disorder. Journal of Learning Disabilities. 2018;51(1):32-42.

4. Diamond A. Executive functions. Annual Review of Psychology. 2013;64:135-168.

5. Cornoldi C, Orsini A, Cianci L, Giofrè D, Pezzuti L. Intelligence and working memory control: Evidence from the WISCIV administration to Italian children. Learning and Individual Differences. 2013;26:9-14.

6. Berninger V, Swanson HL. Diagnosing and treating specific learning disabilities in reference to the brain's working memory system. In Swanson HL, Harris KR, Graham S, editors. Handbook of learning disabilities. New York:Guilford Press;2013.

7. Baddeley A. Working memory: Theories, models, and controversies. Annual Review of Psychology. 2012;63:1-29.
سنى و دانش آموزان شهرهاى ديخر ايران و همجنين ساير توانيىهاى شناختى را نيز مورد توجه قرار دهند. همجنين با توجه به يافتههاى به

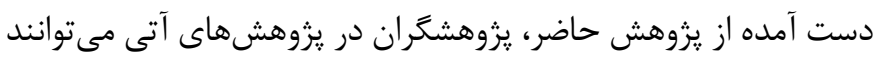

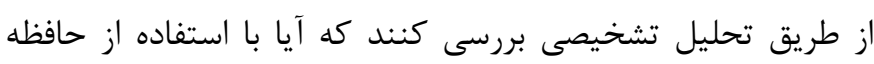

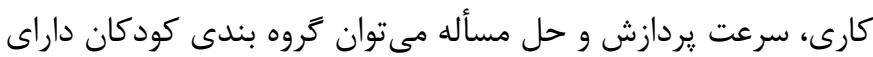

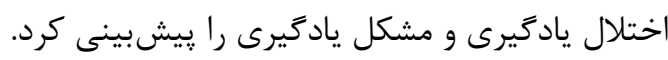

نتيجه كَيرى

توجه به يافتهاى يزوهش حاضر مىتواند كاربردهاى موثرى در بحث تشخيص به هنكام، آموزش و توانبخشى اين دو گروه از دانشآموزان در بى داشته باشد و به كاهش تشخيصهاى مثبت و منفى كاذب و افزايش اعتبار تشخيص در اين حوزه منجر شود. همجنين، نتايج يزوهش حاضر مىتواند در كلينيكهاى درمانى، مدارس و همجنين در طراحى و

8. Baddeley AD. Working memory. London:Oxford University Press; 1986

9. Baddeley A. Exploring the central executive. The Quarterly Journal of Experimental Psychology Section A. 1996;49(1):5-28.

10. Baddeley A. Working memory: Looking back and looking forward. Nature Reviews Neuroscience. 2003;4(10):829-839.

11. Swanson HL. Generality and modifiability of working memory among skilled and less skilled readers. Journal of Educational Psychology. 1992;88(4):473-488.

12. Swanson HL, Siegel L. Learning disabilities as a working memory deficit. Experimental Psychology. 2011;49(1):5-28.

13. Peng P, Fuchs D. A meta-analysis of working memory deficits in children with learning difficulties: Is there a difference between verbal domain and numerical domain?. Journal of Learning Disabilities. 2016;49(1):3-20.

14. Swanson HL, Alloway TP. Working memory, learning, and academic achievement. In Harris KR, Graham S, Urdan T, McCormick CB, Sinatra GM, Sweller J, Editors. APA handbooks in psychology®. APA educational psychology handbook, Vol. 1. Theories, constructs, and critical issues;2012. pp. 327-366. 
15. Swanson HL, Jerman O. Math disabilities: A selective meta-analysis of the literature. Review of Educational Research. 2006;76(2):249-274.

16. Swanson HL. Cognitive profile of adolescents with math disabilities: Are the profiles different from those with reading disabilities?. Child Neuropsychology. 2012;18(2):125-143.

17. Cornoldi C, Giofrè D. The crucial role of working memory in intellectual functioning. European Psychologist. 2014;19(4):260-268.

18. Alloway TP, Gathercole SE. Working memory and neurodevelopmental disorders. Hove:Psychology Press;2006.

19. Maehler C, Schuchardt K. Working memory in children with specific learning disorders and/or attention deficits. Learning and Individual Differences. 2016;49:341-347.

20. Pickering SJ. Working memory and education. San Diego:Academic Pres;2006.

21. Brandenburg J, Klesczewski J, Fischbach A, Schuchardt K, Büttner G, Hasselhorn M. Working memory in children with learning disabilities in reading versus spelling: Searching for overlapping and specific cognitive factors. Journal of Learning Disabilities. 2015;48(6):622-634.

22. Passolunghi MC, Mammarella IC. Selective spatial working memory impairment in a group of children with mathematics learning disabilities and poor problem-solving skills. Journal of Learning Disabilities. 2012;45(4):341-350.

23. Gathercole SE, Pickering SJ. Working memory deficits in children with low achievements in the national curriculum at 7 years of age. British Journal of Educational Psychology. 2000;70(2):177-194.

24. Tolar TD, Fuchs L, Fletcher JM, Fuchs D, Hamlett CL. Cognitive profiles of mathematical problem solving learning disability for different definitions of disability. Journal of Learning Disabilities. 2016;49(3):240-256.

25. Callinan S, Theiler S, Cunningham E. Identifying learning disabilities through a cognitive deficit framework: Can verbal memory deficits explain similarities between learning disabled and low achieving students?. Journal of Learning Disabilities.
2015;48(3):271-280.

26. Poletti M. WISC-IV intellectual profiles in Italian children with specific learning disorder and related impairments in reading, written expression, and mathematics. Journal of Learning Disabilities. 2016;49(3):320-335.

27. Toffalini E, Giofrè D, Cornoldi C. Strengths and weaknesses in the intellectual profile of different subtypes of specific learning disorder: a study on 1,049 diagnosed children. Clinical Psychological Science. 2017;5(2):402-409.

28. Cornoldi C, Giofre D, Orsini A, Pezzuti L. Differences in the intellectual profile of children with intellectual vs. learning disability. Research in Developmental Disabilities. 2014;35(9):2224-2230.

29. Ashkenazi S, Rosenberg-Lee M, Tenison C, Menon V. Weak task-related modulation and stimulus representations during arithmetic problem solving in children with developmental dyscalculia. Developmental Cognitive Neuroscience. 2012;2(Supl1):52-66.

30. Fletcher JM. Classification and identification of learning disabilities. In Wong B, Butler D, Editors, Learning about learning disabilities. New York:Elsevier;2012.

31. Berninger VW, May MO. Evidence-based diagnosis and treatment for specific learning disabilities involving impairments in written and/or oral language. Journal of Learning Disabilities. 2011;44(2):167-183.

32. Berninger VW, Richards TL, Abbott RD. Differential diagnosis of dysgraphia, dyslexia, and OWL LD: Behavioral and neuroimaging evidence. Reading and Writing. 2015;28(8):1119-1153.

33. McCarney SB, Arthaud TJ. The Learning Disability Evaluation Scale-Renormed Second Edition (LDES-R2). Columbia:Hawthorne Educational Services;2007.

34. Sadeghi A, Rabiee M, Abedi MR. Validation and reliability of the Wechsler Intelligence Scale for Children-IV. Developmental Psychology: Journal of Iranian Psychologists. 2011;7(28):377-386. (Persian)

35. Gioia GA, Isquith PK, Guy SC, Kenworthy L. Behaviour 
Rating Inventory of Executive Function-Ages 5-18 (BRIEF). Lutz, Florida:Psychological Assessment Resources;2000.

36. Abdolmohamadi K, Alizadeh H, Ghadiri Sourman Abadi F, Taiebli M, Fathi A. Psychometric properties of Behavioral Rating Scale of Executive Functions (BRIEF) in children aged 6 to 12 years. Quarterly of Educational Measurement. 2018;8(30):135-151.

37. Culbertson CW, Zillmer EA. Tower of London Drexel University (TOL DX): Examiner's manual. North Tonawanda, New York:Multi-Health Systems Incorporated (MHS):1999.

38. Compton DL, Fuchs LS, Fuchs D, Lambert W, Hamlett C. The cognitive and academic profiles of reading and mathematics learning disabilities. Journal of Learning Disabilities. 2012;45(1):79-95.

39. Passolunghi MC, Mammarella IC. Spatial and visual working memory ability in children with difficulties in arithmetic word problem solving. European Journal of Cognitive Psychology. 2010;22(6):944-963.

40. Kail RV. Longitudinal evidence that increases in processing speed and working memory enhance children's reasoning. Psy- chological Science. 2007;18(4):312-313.

41. Bonifacci P, Snowling MJ. Speed of processing and reading disability: a cross-linguistic investigation of dyslexia and borderline intellectual functioning. Cognition. 2008;107(3):9991017.

42. Sheppard LD, Vernon PA. Intelligence and speed of information-processing: A review of 50 years of research. Personality and Individual Differences. 2008;44(3):535-551.

43. Baddeley A. The episodic buffer: A new component of working memory?. Trends in Cognitive Sciences. 2000;4(11):417423.

44. Alloway TP. Automated working memory assessment (AWMA). Oxford:Pearson Education;2007.

45. Alloway TP, Alloway RG. Investigating the predictive roles of working memory and IQ in academic attainment. Journal of Experimental Child Psychology. 2010;106(1):20-29.

46. Preßler AL, Könen T, Hasselhorn M, Krajewski K. Cognitive preconditions of early reading and spelling: a latent-variable approach with longitudinal data. Reading and Writing. 2014;27(2):383-406. 